\title{
Pharmacogenomics in Pediatric Oncology: Review of Gene-Drug Associations for Clinical Use ${ }^{+}$
}

\author{
Vid Mlakar ${ }^{1, *}$, Patricia Huezo-Diaz Curtis ${ }^{1}$, Chakradhara Rao Satyanarayana Uppugunduri ${ }^{1}$, \\ Maja Krajinovic ${ }^{2,3,4}$ and Marc Ansari ${ }^{1,5}$ \\ 1 Cansearch Research Laboratory, Geneva University Medical School, Avenue de la Roseraie 64, \\ 1205 Geneva, Switzerland; patricia.curtis@unige.ch (P.H.-D.C.); \\ chakradhara.uppugunduri@unige.ch (C.R.S.U.); marc.ansari@hcuge.ch (M.A.) \\ 2 Charles-Bruneau Cancer Center, Centre hospitalier universitaire Sainte-Justine, 4515 Rue de Rouen, \\ Montreal, QC H1V 1H1, Canada; maja.krajinovic@umontreal.ca \\ 3 Department of Pediatrics, University of Montreal, 2900 Boulevard Edouard-Montpetit, \\ Montreal, QC H3T 1J4, Canada \\ 4 Department of Pharmacology, Faculty of Medicine, University of Montreal, 2900 Boulevard \\ Edouard-Montpetit, Montreal, QC H3T 1J4, Canada \\ 5 Pediatric Department, Onco-Hematology Unit, Geneva University Hospital, Rue Willy-Donzé 6, \\ 1205 Geneva, Switzerland \\ * Correspondence: vid.mlakar@unige.ch; Tel.: +41-22-372-38-29 \\ $+\quad$ This paper was published on behalf of the Pediatric individualized treatment in oncology and hematology \\ committee of the European Society of Pharmacogenomics and Personalised Therapy (ESPT).
}

Academic Editor: William Chi-shing Cho

Received: 21 July 2016; Accepted: 15 August 2016; Published: 8 September 2016

\begin{abstract}
During the 3rd congress of the European Society of Pharmacogenomics and Personalised Therapy (ESPT) in Budapest in 2015, a preliminary meeting was held aimed at establishing a pediatric individualized treatment in oncology and hematology committees. The main purpose was to facilitate the transfer and harmonization of pharmacogenetic testing from research into clinics, to bring together basic and translational research and to educate health professionals throughout Europe. The objective of this review was to provide the attendees of the meeting as well as the larger scientific community an insight into the compiled evidence regarding current pharmacogenomics knowledge in pediatric oncology. This preliminary evaluation will help steer the committee's work and should give the reader an idea at which stage researchers and clinicians are, in terms of personalizing medicine for children with cancer. From the evidence presented here, future recommendations to achieve this goal will also be suggested.
\end{abstract}

Keywords: pediatrics; pharmacogenomics; PharmGKB; thiopurine; cisplatin; methotrexate; cyclophosphamide; irinotecan

\section{Introduction}

Twenty percent of pediatric cancer patients do not respond to standard therapy [1] and 22\% of all hospital admissions in this population is due to adverse drug reactions (ADRs) [2]. The therapeutic agents used in cancer chemotherapy are often administered at high doses [3], which due to inter-patient variability and narrow therapeutic ranges result in a spectrum of outcomes from severe toxicities to underexposure. Part of this variability can be attributed to heritable genetic variations affecting the drug pharmacokinetics and pharmacodynamics. The study of the relationship between genetics and drug function is most commonly known as pharmacogenetics or pharmacogenomics. Pharmacogenomics has the potential to improve the drug safety and efficacy and is recognized as a valid approach to personalize treatment $[4,5]$. 
Patients respond differently to medication due to their constitutive genetic variations but also due to mutations or epigenetic signatures acquired during the process of neogenesis or treatment. The intention of this review is to focus on germline variations that might affect treatment efficacy and toxicity. For a detailed revision of acquired mechanisms of cancer resistance, we recommend reviews by Holohan et al. and Longley et al. [6,7].

The establishment of a pediatric individualized treatment in oncology and hematology committee was proposed during the 3rd congress of The European Society of Pharmacogenomics and Personalised Therapy (ESPT) (Budapest, Hungary, 7-9 October 2015) with the aim to facilitate the transfer and harmonization of pharmacogenetics testing in children, bring together basic and translational research, educate health professionals throughout Europe and establish partnerships for industry and regulatory bodies. A summary of our current knowledge in pharmacogenomics is essential to achieve these aims.

\section{The Role of Ontogeny in Pharmacogenomics}

Pharmacogenomics in children, unlike adults, must be viewed in the context of body development in addition to the physiological changes due to illness. As the child grows into an adult, changes occur in the body composition. For example, premature neonates of approximately $1.5 \mathrm{~kg}$ have $3 \%$ of body fat, which raises to $12 \%$ by the 40 th week of gestation; and then up to $25 \%$ by the 4 th month of age. Similarly, protein mass increases from $20 \%$ at birth to $50 \%$ in the adult [8]. These changes must be considered when analyzing the differences in pharmacokinetic data in relation to the genotypes. Another issue of importance for clinical utility of pharmacogenetic tests in children is ontogeny of drug metabolizing enzymes (DMEs) (Phase 1 and 2), transporters, and target proteins. A prime example is development of drug metabolism capability associated with expression of P450 cytochromes (CYP) [9]. Enzymes of the CYP3A family have been shown to substantially change their activity from foetus to adulthood. The family has four members in humans: 3A4, 3A5, 3A7 and 3A43. CYP3A4 is the most abundantly expressed CYP in liver and small intestine accounting for $30 \%-40 \%$ of CYP proteins. CYP3A4 has extremely low activity at birth, reaching approximately $30 \%-40 \%$ of adult activity by the first month and full adult activity by the 6th month; exceeding adult activity $(120 \%)$ between 1 and 4 years of age, decreasing to adult levels after puberty [10]. CYP3A5 is $83 \%$ homologous with CYP3A4 and is expressed in kidney and in liver but at lower levels. CYP3A5 with CYP2B6 are the only two CYPs along with a phase II enzyme $N$-acetyl transferase with no variable expression from childhood to adulthood suggesting equal importance of their genetic variants at every developmental stage. CYP3A7 is 90\% homologous with CYP3A4 and is mostly expressed in embryonic, foetal and new-born liver [11]. Similar variability in expression during development is noted for CYP2D6. It was demonstrated that foetuses less than 30 weeks old show less than 5\% of CYP2D6 activity in comparison to adults. After birth, the activity gradually increases such that between day 7 and 28 the activity is $30 \%$ and between 4 weeks and 5 years the activity is $70 \%$ to that of adults [12]. In addition CYP expression and activity can be affected by common health problems such as non-alcoholic fatty liver disease and neonatal diabetes.

Much like DMEs, ontogeny of drug transporters and drug targets is also important when it comes to the evaluation and implementation of pharmacogenetics. Multidrug resistance protein 1 (MDR1 or $\mathrm{P}$-gp) and ATP binding cassette (ABC) G2 are expressed early in childhood, whereas other transporters like organic anion transporter (OATP1B1) and multidrug resistant protein 2 (MRP2) exhibit delayed maturation and reduced expression levels during the first months of childhood compared to adults [13].

The above described cases are just a few examples of ontogeny contribution to gene expression differences. A recent publication [14] showed that up to 688 genes are differentially expressed during childhood development only in lymphoblastic cells. Using gene expression profiling of lymphoblast cells, researchers were able to distinguish three particular groups: pre-pubertal (under 6), pubertal (from 6 to 17) and early adulthood group (older than 17) [5,14] suggesting a set of developmental genes which are expressed in an independent manner [5,15]. 
The importance of ontogeny is reflected by different responses to the same drug by children and adults. Higher susceptibility to ototoxicity with cisplatin treatment $[16,17]$, effects on neurological development linked to methotrexate [18], higher clearance of tacrolimus or unresponsiveness to codeine in infants [19] are but a few such examples. Lastly, certain diseases such as acute lymphoblastic leukemia (ALL), neuroblastoma (NB) and osteosarcoma (OS) appear predominantly in children and must be therefore linked to ontogeny, providing additional support that pediatric pharmacogenomics should be considered as a distinct field. Scarcity of information and consensus on ontogeny is still one of the major limitations for a clear understanding of utility of genetic variants [20].

\section{Methods}

The initial step prior to assessing gene-drug relationships was to list all the current major drugs in Europe used to treat the following conditions in children: leukemias, lymphomas, brain tumors and solid tumors (see Supplementary Materials Table S1) [21]. In order to simplify the search, only primary drugs were included and supportive treatment such as prophylaxis drugs or co-medications were excluded. The second step was to identify whether these drugs already had established gene relationships on The Pharmacogenomics Knowledgebase (PharmGKB, https:/ /www.pharmgkb. $\mathrm{org} /$ ) web-based database or are incorporated in clinical guidelines of Clinical Pharmacogenetics Implementation Consortium (CPIC) (Figure 1). PharmGKB is an online comprehensive resource that curates knowledge on the impact of genetic variations on drug responses for clinicians and researchers. It is dedicated to systematically extract and evaluate evidence for gene/drug associations from scientific databases. PharmGKB collaborates closely with CPIC whose task is to prepare clinical guidelines for gene/drug pairs that satisfy the highest standards of evidence and has clinical significance [22].

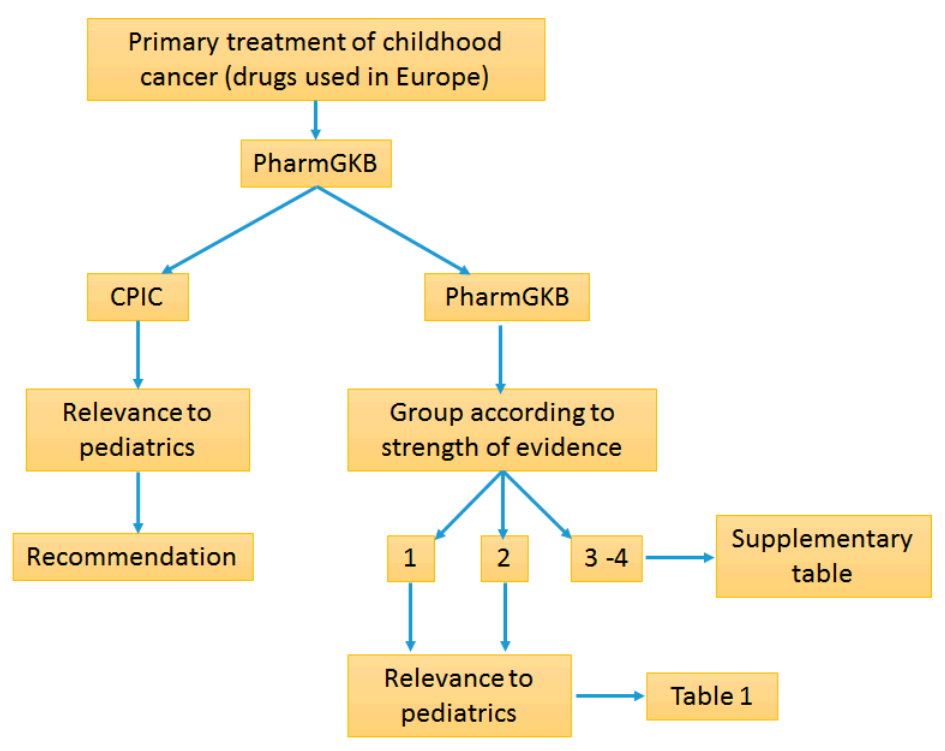

Figure 1. Methodology flow chart.

Flowchart of methodology used to extract information on pediatric oncology pharmacogenomics. First, drugs used in Europe were defined (Supplementary Materials Table S1). CPIC and PharmGKB was used to search for guidelines and drug/gene associations and strength of evidence. Genes were grouped according to the evidence in three groups (Supplementary Materials Table S1). Lastly, studies published in children and pediatric sections of CPIC were selected and reviewed (Table 1). 
Table 1. Gene-drug pairs with high and moderate (Group 1 and 2) evidence of association as graded by PharmGKB.

\begin{tabular}{|c|c|c|c|c|c|c|c|c|c|c|c|c|}
\hline $\begin{array}{l}\text { Evidence } \\
\text { Level }\end{array}$ & Drug & Gene & Allele/Variant & AFR & EAS & EUR & Effect & $\begin{array}{c}\text { Total } \\
\text { Articles }\end{array}$ & $\begin{array}{l}\text { Pediatric } \\
\text { Articles }\end{array}$ & All ref. & Ped. ref. & Condition (Pediatric) \\
\hline \multirow{5}{*}{ Level 1} & \multirow{4}{*}{ Thiopurines } & \multirow{3}{*}{ TPMT } & $*^{*}$ rs1800462 & 0.001 & 0.000 & 0.006 & \multirow{3}{*}{ Dosage, Toxicity/ADR } & \multirow{3}{*}{96} & \multirow{3}{*}{30} & \multirow{3}{*}{ [23-119] } & \multirow{3}{*}{ [89-118] } & \multirow{3}{*}{$\begin{array}{l}\text { Acute lymphoblastic } \\
\text { leukemia }\end{array}$} \\
\hline & & & $\begin{array}{l}{ }^{*} 3 \mathrm{~B} \text { rs } 1800460 \\
{ }^{*} \mathrm{C} \text { rs } 1142345\end{array}$ & $\begin{array}{l}0.003 \\
0.067\end{array}$ & $\begin{array}{l}0.000 \\
0.022\end{array}$ & $\begin{array}{l}0.028 \\
0.029\end{array}$ & & & & & & \\
\hline & & & ${ }^{*} 4 \mathrm{rs} 1800584$ & NA & $\begin{array}{l}0.022 \\
\text { NA }\end{array}$ & $\begin{array}{l}0.029 \\
\text { NA }\end{array}$ & & & & & & \\
\hline & & NUDT15 & $\begin{array}{l}* 2 \text { and } * 3 \\
\text { rs } 116855232\end{array}$ & 0.008 & 0.095 & 0.002 & Dosage, Toxicity/ADR & 9 & 6 & [120-132] & {$[120-126]$} & $\begin{array}{c}\text { Acute lymphoblastic } \\
\text { leukemia }\end{array}$ \\
\hline & Cisplatin & XPC & rs2228001 & 0.249 & 0.333 & 0.405 & Toxicity/ADR & 2 & 1 & {$[133,134]$} & [133] & Osteosarcoma \\
\hline \multirow{13}{*}{ Level 2} & \multirow{4}{*}{ Cisplatin } & ERCC1 & $\begin{array}{l}\text { rs3212986 } \\
\text { rs11615 }\end{array}$ & $\begin{array}{l}0.291 \\
0.037\end{array}$ & $\begin{array}{l}0.299 \\
0.262\end{array}$ & $\begin{array}{l}0.250 \\
0.622\end{array}$ & Efficacy, Toxicity/ADR & 11 & 0 & [135-147] & & NS \\
\hline & & GSTM1 & Null & NA & NA & NA & Efficacy & 3 & 0 & [148-150] & & NS \\
\hline & & TP53 & rs1042522 & 0.669 & 0.414 & 0.285 & Efficacy, Toxicity/ADR & 5 & 0 & {$[139,140,151-153]$} & & NS \\
\hline & & XRCC1 & rs25487 & 0.110 & 0.235 & 0.366 & Toxicity/ADR & 9 & 0 & [136-140,154-157] & & NS \\
\hline & \multirow{4}{*}{ Carboplatin } & EGFR & rs121434568 & NA & NA & NA & Efficacy & 8 & 0 & [158-165] & & NS \\
\hline & & ERCC1 & rs11615 & 0.037 & 0.262 & 0.622 & Efficacy, Toxicity/ADR & 11 & 0 & [135-147] & & NS \\
\hline & & MTHFR & rs1801133 & 0.090 & 0.296 & 0.365 & Efficacy & 2 & 0 & {$[166,167]$} & & NS \\
\hline & & XRCC1 & rs25487 & 0.110 & 0.235 & 0.366 & Efficacy, Toxicity/ADR & 9 & 0 & [136-140,154-157] & & NS \\
\hline & \multirow{5}{*}{ Methotrexate } & $A B C B 1$ & rs1045642 & 0.150 & 0.398 & 0.518 & Toxicity/ADR & 3 & 2 & [168-170] & {$[168,170]$} & Lymphoma \\
\hline & & ATIC & rs4673993 & 0.095 & 0.294 & 0.313 & Efficacy & 2 & 0 & {$[171,172]$} & & NS \\
\hline & & MTHFR & rs1801133 & 0.090 & 0.295 & 0.365 & Efficacy, Toxicity/ADR & 37 & 26 & {$[100,169,170,173-206]$} & {$[100,170,173-196]$} & $\begin{array}{c}\text { Acute lymphoblastic } \\
\text { leukemia }\end{array}$ \\
\hline & & MTRR & rs1801394 & 0.246 & 0.263 & 0.523 & $\begin{array}{c}\text { Toxicity/ADR, } \\
\text { Metabolism/PK }\end{array}$ & 3 & 3 & {$[185,207,208]$} & {$[185,207,208]$} & $\begin{array}{c}\text { Acute lymphoblastic } \\
\text { leukemia }\end{array}$ \\
\hline & & SLCO1B1 & rs11045879 & 0.189 & 0.453 & 0.190 & Toxicity/ADR & 4 & 3 & [209-212] & [209-211] & $\begin{array}{c}\text { Acute lymphoblastic } \\
\text { leukemia }\end{array}$ \\
\hline \multirow{7}{*}{ Level 2} & \multirow{4}{*}{ Cyclophosphamide } & GSTP1 & rs1695 & 0.480 & 0.179 & 0.331 & Efficacy, Toxicity/ADR & 2 & 0 & {$[213,214]$} & & NS \\
\hline & & MTHFR & rs1801133 & 0.090 & 0.296 & 0.365 & Toxicity/ADR & 3 & 1 & {$[151,188,204]$} & [188] & Osteosarcoma \\
\hline & & SOD2 & rs 4880 & 0.424 & 0.125 & 0.466 & Efficacy & 1 & 0 & [215] & & NS \\
\hline & & TP53 & rs1042522 & 0.669 & 0.414 & 0.285 & Efficacy, Toxicity/ADR & 5 & 0 & {$[139,140,151-153]$} & & NS \\
\hline & \multirow{3}{*}{ Irinotecan } & C8orf34 & rs1517114 & 0.424 & 0.122 & 0.363 & Toxicity /ADR & 1 & 0 & [216] & & NS \\
\hline & & SEMA3C & rs7779029 & 0.365 & 0.152 & 0.047 & Toxicity/ADR & 1 & 0 & [216] & & NS \\
\hline & & UGT1A1 & $\begin{array}{l}\text { rs8175347 } \\
\text { rs4148323 }\end{array}$ & $\begin{array}{c}\mathrm{NA} \\
0.001\end{array}$ & $\begin{array}{c}\text { NA } \\
0.138\end{array}$ & $\begin{array}{c}\text { NA } \\
0.007\end{array}$ & Toxicity/ADR & 35 & 1 & [217-254] & [249] & Solid tumors \\
\hline
\end{tabular}

Description of columns: 1: Evidence level; 2: drug name; 3: genes associated with drug; 4: genetic variant investigated; 5-7: Minor allele frequencies (MAF) were obtained from 1000 Genomes Consortium, Phase 3_V1-: AFR—African, EUR—European, EAS—East Asian; 8: Pharmacogenetic effect, 9: total number of articles; 10: number of pediatric articles; 11:

references of total articles; 12: references of pediatric articles; 13: pediatric condition under investigation. NA—not available, NS—no study, PK—pharmacokinetic. 
PharmGKB curators rate gene/drug associations into four broad groups based on the strength (1 strongest to 4 weakest) of evidence for association. In short, level 1 includes gene/drug associations that show significant $p$ values in more than one cohort and preferably with strong effect size; Level 2 includes associations that were replicated but other studies that do not show significance may be present and/or association shows small effect size; Level 3 is based on single studies showing significant association but the evidence has not been replicated; Level 4 is based on case reports, in vitro, molecular or other functional assays only (for a detailed explanation please refer to the original manuscript) [22]. The system used in this review adapted the PharmGKB approach with a few modifications in that group 3 and 4 were combined into a single group of low evidence gene/drug associations having low probability of entering clinical level at the time and group 1 and 2 remained separate (see Table S1). Next, we extracted publications on drug/gene associations with high and moderate evidence (Groups 1 and 2) for drugs most commonly used in pediatric oncology medicine. Each publication was checked for patient population used. Publications in pediatrics were extracted and used for review. Lower evidence drug/gene pairs (Levels 3 and 4) were discussed in case it contributed to better understanding of higher level drug/gene associations.

\section{Results}

\subsection{Drugs with Strong Pharmacogenetics Evidence}

From the initial screen, we were able to identify the following drug/gene pairs with strong pharmacogenetic evidence (Group 1): thiopurines/thiopurine S-methyltransferases (TPMT), thiopurines/nudix hydrolase 15 (NUDT15) and cisplatin/Xeroderma Pigmentosum, Complementation Group C (XPC) (Table 1) with thiopurines/TPMT already having published guidelines by CPIC [255,256].

\subsubsection{Thiopurines/Thiopurine S-Methyltransferases (TPMT) Pair}

Pharmacogenomics of thiopurines (6-mercaptopurine (6MP) and 6-thioguanine (6TG)) with TPMT is probably the most studied drug/gene interaction in pediatric medicine. Thiopurines are applied as prodrugs that are converted into thioguanine nucleotides (TGNs) by hypoxanthine guanine phosphoribosyl transferase (HPRT) (Figure 2). TGNs are cytotoxic compounds that integrate into the DNA and RNA causing nucleic acid damage that ultimately leads to cancer cell death. TGNs can trigger apoptosis in normal immune cells causing serious ADRs mainly neutropenia, thrombocytopenia and hepatotoxicity manifested as veno-occlusive disease [95,106,111]. Inactivation of TGNs is carried out through S-methylation by cytosolic TPMT. Polymorphisms in the gene have been shown to exert an influence on TPMT activity [257,258]. For clinical purposes, individuals are divided into three major groups: normal, intermediate and poor metabolizers based on the presence of one or two loss of function alleles. Alleles $* 2, * 3 \mathrm{~A}, * 3 \mathrm{~B}$ and $* 3 \mathrm{C}$ are by far the most common variant alleles and are estimated to predict up to 90\% of TPMT function and variability [259]. An additional 34 TPMT alleles have been described in different populations but with much lower frequencies [260].

This drug/gene association has important clinical implications because the treatment outcome of childhood ALL with 6MP is highly associated with maximum tolerable drug dose [111]. This is based on the observations of an inverse relationship between concentration of TGNs and TPMT genotype and the ability of the patients to tolerate full doses of 6MP. TPMT-poor metabolizers tolerated full $6 \mathrm{MP}$ dose only for $7 \%$ of the total weeks, in contrast to $65 \%$ and $84 \%$ for TPMT-intermediate and TPMT-normal metabolizers, respectively. TPMT-normal metabolizers missed only $2 \%$ of total treatment weeks, in contrast to $16 \%$ and $76 \%$ of missed weeks for TPMT-intermediate and TPMT-poor metabolizers, respectively [111]. Guidelines developed by CPIC recommend a normal dose for normal metabolizers. For intermediate metabolizers, a $30 \%-70 \%$ reduction is recommended for $6 \mathrm{MP}$ and a $30 \%-50 \%$ reduction for $6 \mathrm{TG}$. Poor metabolizers receiving $6 \mathrm{MP}$ or $6 \mathrm{TG}$ should receive a $90 \%$ reduction in dose with drug administration three times per week in order to avoid ADRs (Table 2). Pre-emptive 
patient testing is highly recommended either to avoid adverse drug reactions in case of malignant disease or to reduce time needed for upward titration of drug dosage [256,261].

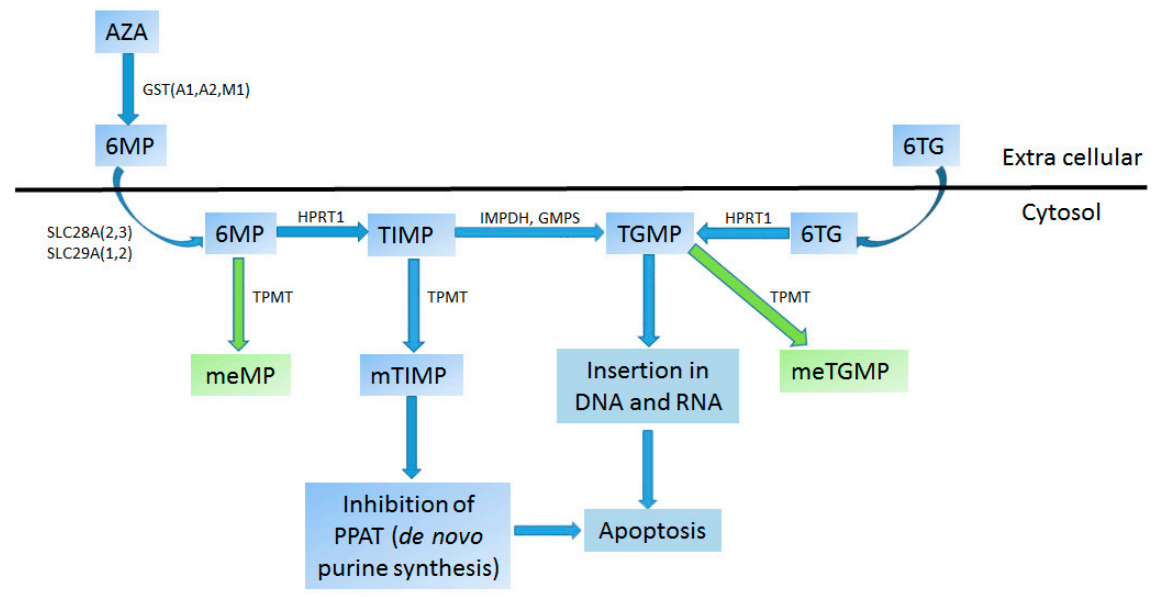

Figure 2. Metabolism of thiopurine $S$-methyltransferases (TPMT). Metabolite: Azathioprine (AZA), Methylmercaptopurine (meMP), Methyl-thioguanosine monophosphate (meTGMP), Methyl-thioinosine monophosphate (mTIMP), Thioguanosine monophosphate (TGMP), Thioinosine monophosphate (TIMP), 6-mercaptopurine (6MP), 6-thioguanine (6TG). Enzyme: Glutathione-S-transferase A1, A2, M1 (GSTA1, GSTA2, GSTM1), Guanosine monophosphate synthetase (GMPS), Hypoxanthine guanine phosphoribosyl transferase (HPRT1), Inositol monophosphate dehydrogenase (IMPDH), Thiopurine methyltransferase (TPMT), Solute carrier family 8A2, 8A3, 29A1, 29A2 (SLC28A2, SLC28A3, SLC29A1, SLC29A2). Colors: blue-prodrug, drug or effect; green-inactive metabolites (adapted from [262]).

Table 2. Dosing guidelines for 6MP and TG based on the presence phenotype/genotype of TPMT.

\begin{tabular}{ccc}
\hline TPMT Phenotype/Genotype & Dosing Recommendation 6MP & Dosing Recommendation 6TG \\
\hline $\begin{array}{c}\text { Normal metabolizer } \\
\text { (two functional alleles) }\end{array}$ & Start with normal dose & Start with normal dose \\
\hline $\begin{array}{c}\text { Intermediate metabolizer } \\
\text { (one functional allele) }\end{array}$ & Start with $30 \%$ to $70 \%$ reduced dose & Start with $30 \%$ to $50 \%$ reduced dose \\
\hline $\begin{array}{c}\text { Poor metabolizer } \\
\text { (no functional alleles) }\end{array}$ & Start with $90 \%$ reduced dose, trice weekly & Start with $90 \%$ reduced dose, trice weekly \\
\hline
\end{tabular}

Recognizing the importance of ontogeny, CPIC reviewed the evidence on thiopurines/TPMT relationship gathered in pediatric cohorts and published a revised guideline in 2013. Because childhood leukemia is the most common childhood neoplastic disease, a large number of studies have been conducted in the pediatric population. However, evidence in children does not deviate from that seen in adults [255] and the revised CPIC guidelines do not recommend any specific adaptation for pediatric use [255].

\subsubsection{Thipurines/Nudix Hydrolase 15 (NUDT15) Pair}

TPMT genotyping explains significant variability in response to treatment with thiopurines but substantial toxicities still occur in some patients with normal TPMT activity, suggesting other genetic predispositions must be involved in patient variability in thiopurine metabolism [123]. Recently, several replicating studies have shown that dose adjustment based on presence of low activity NUDT15 variant (Arg139Cys) should be made in children receiving 6MP for treatment of ALL $[120,122,123,125,126]$. In addition, the low activity allele was associated with alopecia and leukopenia in children treated with azathioprine $[121,125,128,129]$ and myelosuppression in children 
treated for ALL with 6MP $[120,128]$. Moriyama et al. recently found three additional loss of function single nucleotide polymorphisms (SNPs) comprising at present four different loss of function alleles designated ${ }^{*} 2-55$ that were associated with thiopurine metabolism [123]. NUDT15 is a member of nudix hydrolase superfamily. It is homologous to nudix hydrolase 1 (MTH1) which is involved in the hydrolysis of 8-oxo-2'-deoxyguanosine-5' -triphosphate (8-oxo-dGTP), produced by oxidative damage, causing transversions due to DNA mispairing. Crystal structure and biochemical testing of NUDT15 have shown low catalytic activity towards deoxycytidine triphosphate (dCTP), deoxythymidine triphosphate (dTTP) and 8-oxo-dGTP but it has strongest activity against thiopurine derivatives of guanine (6-thio-dGTP). In addition, the same polymorphism associated with the above described clinical consequences have been shown to adversely affect NUDT15 activity. This suggests that a pool of normal guanine in cells having poor metabolizing variant of NUDT15 is affected more by thiopurines in comparison to cells carrying normal metabolizing NUDT15 gene [263]. Although more evidence in terms of prospective clinical trials has to be gathered, NUDT15 presents probably the most likely candidate for implementation of clinical guidelines because of its large effect and clinical significance especially in Asian populations with less frequent TPMT dysfunctional alleles. A recent study by Moriyama et al. suggests that, similarly with TPMT, NUDT15 variants would likely benefit by tailoring dosing against the levels of thioguanosine triphosphate and thioguanosine-DNA giving a valuable direction for execution of further studies [123].

\subsubsection{Cisplatin/Xeroderma Pigmentosum, Complementation Group C (XPC) Pair}

Cisplatin was the first platinum based chemotherapeutic used for the treatment of various types of cancers. It is, for example, highly effective for the treatment of neuroblastoma, osteosarcoma, hepatoblastoma and brain tumors predominantly found in children. Cisplatin acts as a DNA damaging agent through three different pathways: alkylating DNA, crosslinking guanines or inducing nucleotide mispairing. Because these events interfere with replication and transcription, cisplatin exerts cytotoxic function irrespective of the cell cycle. Cisplatin is mainly cleared through the kidney [264]. Although treatment with cisplatin has contributed greatly to overall survival of pediatric cancer patients its use comes at a cost [265]. The most severe ADRs in children are nephrotoxicity, neurotoxicity and ototoxicity $[16,17]$. A study looking at long-term effects of cisplatin found persistence of nephropathy even 10 years after treatment [266]. Ototoxicity in children is of particular concern because it can impair speech and normal development. A recent and ongoing clinical trial of Childhood liver tumors study group (SIOPEL-4) observed moderate or severe ototoxicity in $50 \%$ of children treated with cisplatin for high-risk hepatoblastoma [267]. Other studies in children with medulloblastoma, osteosarcoma and neuroblastoma detected permanent hearing damage in $60 \%$ of patients receiving cisplatin [268]. Based on the rationale that DNA repair mechanisms are involved in repairing damaged DNA caused by cisplatin, several studies explored the possibility of drug resistance, survival and toxicity association with particular DNA repair gene variations. Indeed, XPC gene of the nucleotide excision repair pathway (NER) was associated with ototoxicity in children and young adults treated for osteosarcoma [133]. An independent study showed the same XPC gene variant is associated with cisplatin induced neutropenia and hematological toxicity in adult patients treated for bladder cancer [134]. Even though evidence produced so far looks promising in terms of prediction of ADRs in patients receiving cisplatin, it must be emphasized that these two studies were performed on different patient populations with different treatment protocols. Further replication studies on a broader spectrum of cisplatin receiving patients are needed to verify the observed results before any guidelines can be established. The next question is related to the clinical utility of this particular association in light of inadequate replacement drugs or recommended dose intensity [269] and measures that can be taken to prevent ADRs. One option could be the refinement of cisplatin protocols to the levels that may minimize the ADRs or substituting with other platinum based chemotherapeutics like carboplatin that might produce less ADRs but still achieve the same efficacy. 


\subsection{Drugs with Moderate Pharmacogenetics Evidence}

This section describes gene/drug associations with moderate strength of association according to PharmGKB. Table 1 summarizes drugs and their association with genes and variants, effect of variants, total number of publications, published in pediatric populations with details of the cohort analyses.

\subsubsection{Cisplatin and Carboplatin}

Other moderate evidence genes associated with cisplatin are from the DNA damage repair pathways. Excision repair core complex (ERCC) 2, a helicase and a vital component of the NER pathway known to be involved in removal of DNA adducts formed after platinum treatment, was found to be useful for predicting clinical outcomes of osteosarcoma in children and young adults [133]. Other genes that present interesting targets for investigation in the context of pediatric patients are tumor protein 53 (TP53) [140,153], X-ray repair cross complementing 1 (XRCC1), ERCC1 [140,142,144,155,157], methylenetetrahydrofolate reductase (MTHFR) [166,167] and GSTM1 [148-150]. Their association with cisplatin and carboplatin is placed in level 2 evidence, however, no pediatric studies have been performed to date.

A pharmacogenetic study in children showed that hearing loss due to cisplatin treatment is associated with TPMT loss of function alleles [270]. Because of that, the Food and Drug Administration (FDA) had issued a special precaution on cisplatin drug labels stating that individuals with allele $T_{P M T}{ }^{*} 3 B$ and TPMT ${ }^{*} 3 C\left({ }^{*} 3 \mathrm{~A}\right.$ is haplotype of ${ }^{*} 3 \mathrm{~B}$ and $\left.{ }^{*} 3 \mathrm{C}\right)$ are at a higher risk of hearing loss [270]. Despite the initial strong evidence between TPMT and cisplatin, PharmGKB qualified it as a level $3 \mathrm{drug} /$ gene pair due to the lack of replication. In addition, two studies were unable to reproduce the association [271,272]; a third study was performed by the same group that reported the original association, this time with a smaller effect size [273], prompting the FDA to remove TPMT associated precautions from the cisplatin drug label.

\subsubsection{Methotrexate}

Methotrexate (MTX) is a folate analogue that inhibits dihydrofolate reductase (DHFR), which converts dihydrofolate (DHF) to tetrahydrofolate (THF) needed for several one-carbon transfer reactions in nucleotide synthesis (Figure 3) [274].

MTX has been known for more than 60 years and was the first rationally designed molecule against cancer [275]. MTX remains an important anticancer agent, it is an essential component of consolidation and continuation therapy against ALL [276-279]. Despite the successful improvement of dosing regimens, there is still variability in therapeutic responses to MTX. There are a subset of patients who are more prone to the development of MTX-associated ADRs [274,278], whereas resistance to MTX remains a significant problem reducing the efficacy of the therapy. Resistance may arise through adaptation of cancer cells exposed to MTX, but can also be facilitated by genetic predispositions mainly involving variations in genes of folate metabolism, folate dependent enzymes and influx/efflux systems [274,278].

A most notable example of influx transporters is that of solute carrier organic anion transporter family member 1B1 (SLCO1B1 or OATP1B1) which was associated with high dose MTX clearance and toxicity [210,212,280]. Several SNPs in linkage disequilibrium (LD), including rs11045879, were in association, however, it is rs4149056 that was shown to have reduced MTX influx capacity [280]. A description of clinically important haplotypes in SLCO1B1 is available at PharmGKB due to the involvement of the same gene in modulation of response to statins. This may be relevant for MTX use, especially for taking precautionary measures such as alkalization or increased hydration in carriers of dysfunctional SLCO1B1 alleles. OATP1 expression levels are lower at birth and early childhood, but then slowly increase to reach adult levels after the age of 7 with genetic variants playing a major role in inter-individual variability in its expression at mature state [281,282]. ABCB1, another level 2 drug/gene pair, encodes a MTX exporter protein [168-170]. ABCB1-3435C $>$ T was found to be 
associated with increased risk of neutropenia in Lebanese pediatric ALL patients [170] and with anemia and thrombocytopenia in a Danish population [168]. The other efflux transporters, ranked in a lower evidence group, like $\mathrm{ABCC} 3$ and $\mathrm{ABCC} 4$ also influenced the risk of relapse and ADR in childhood ALL $[283,284]$. Reduced folate carrier (RFC1) is responsible for MTX import. Even though at higher MTX doses uptake transporters might not play a major role, there are conflicting results on RFC1 genetic variant and MTX response with higher incidence of relapse in individuals carrying defective $R F C 1$ variants $[187,285,286]$.

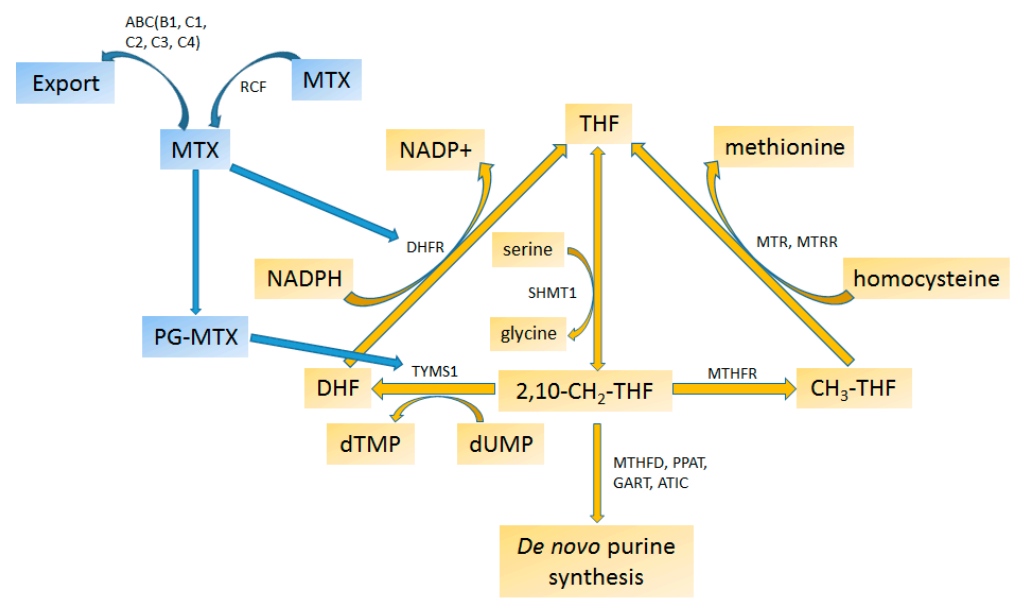

Figure 3. Functioning of Methotrexate. Metabolite: Dihydrofolate (DHF), Methotrexate (MTX), Methotrexate polyglutamate (PG-MTX), Methyl-tetra-hydrofolate $\left(\mathrm{CH}_{3}-\mathrm{THF}\right)$, Methylene-tetrahydrofolate $\left(2,10-\mathrm{CH}_{2}-\mathrm{THF}\right)$, Nicotinamide adenine dinucleotide phosphate (NADP), Tetrahydrofolate (THF), Thymidine monophosphate (dTMP), Uridine monophosphate (dUMP). Enzyme: ATP binding cassette subfamily B1, C1, C2, C3, C4, (ABCB1, ABCC1, ABCC2, ABCC3, ABCC4,), Dihydrofolate reductase (DHFR), serine hydroxymethyltransferase 1 (SHMT1), Formyltetrahydrofolate synthetase (MTHFD), Methylenetetrahydrofolate reductase (MTHFR), Phosphoribosyl pyrophosphate amidotransferase (PPAT), Phosphoribosylglycinamide synthetase (GART), Replication factor C subunit 1 (RFC), Thymidylate synthase (TYMS1), 5-aminoimidazole-4-carboxamide ribonucleotide formyltransferase/IMP cyclohydrolase (ATIC), 5-methyltetrahydrofolate-homocysteine methyltransferase (MTR), 5-methyltetrahydrofolate- homocysteine methyltransferase reductase (MTRR). Colors: blue-active drug or metabolite; golden-endogenous metabolite (adapted from $[22,207])$.

Pharmacogenomic association studies intensively investigated genes of THF and MTX metabolism. MTHFR, responsible for conversion of 2,10- $\mathrm{CH}_{2}$-THF into $\mathrm{CH}_{3}$-THF and a main target of MTX, was most heavily investigated. Substantial evidence shows that MTHFR variants are associated with haematological toxicities [100,174], survival $[180,190]$ and dose exposure [196] in children with ALL. However, two recent meta-analyses by Lopez-Lopez et al. and Hagleitner et al., concluded that variants of MTHFR were not good markers for toxicity and ADRs in pediatric ALL [179,186]. In contrast, a third meta-analysis was able to show positive association of C677T with relapse in childhood ALL [180]. The reason for discrepancies between meta-analysis and other studies are unknown but factors such as regiment protocols, patient populations and outcomes might obscure the effect otherwise presentable in a more homogeneous study group. 5-Methyltetrahydrofolate-homocysteine methyltransferase reductase (MTRR), involved in conversion of homocysteine to methionine was found to be associated with oral mucositis, increased platelet recovery [208] and increased thymidylate synthase (TYMS) catalytic activity [207] but not with decreased intelligence quotient (IQ) [185] in pediatric ALL patients.

Other genes from the THF metabolism, DHFR, TYMS and SHMT1, were assigned to a lower evidence group either because of contradictory reports or lack of replication in their association with ADRs, efficacy or pharmacokinetic. Variations in DHFR, a main MTX target converting DHF into THF, 
were shown to be associated with increased risk of relapse [287-289] and thrombocytopenia [190]. Another important enzyme, TYMS, that converts 2,10- $\mathrm{CH}_{2}$-THF to DHF, was found to be associated with relapse [290,291], stomatitis [286] or osteonecrosis [292] in children with ALL. There are however others that did not observe such association [187] or observe it only through interaction with other genes [177]. TYMS was also found to be associated with oral mucositis in patients receiving hematopoetic cell-transplantation [204]. Interestingly, increased catalytic activity of TYMS seems to correlate with SHMT1 and MTRR variations [207]. Association studies on SHMT1 were contradictory and few. One study found an association with liver toxicity in children receiving MTX treatment for ALL [208] while another did not detect the association with drug toxicity [177].

Even though metabolism of THF and MTX is well known, it is complex in terms of biochemistry and genetic variability. Ontogeny of these enzymes is not fully understood as shown, for example, by animal studies where variations in the expression of MTHFR genes of liver, kidneys and brain tissues during early foetal life and in neonates [293] were reported, suggesting that enzymatic phenotyping could add valuable data to genetic association studies. In addition, association studies used several different variations showing the need for harmonization by using the same variations in order to increase the power. One of the concerns in most of these studies is the definition of clinical outcomes, consideration of uniformity, and having more precision within the guidelines. Conducting explorative or replication studies with uniform design will enable evaluating the evidence in a systematic fashion with due consideration of multiple genes while controlling for confounders.

\subsubsection{Cyclophosphamide}

Cyclophosphamide (CP) is used for treatment of various common [294,295] and rare childhood solid tumors such as osteosarcoma [296], Ewing sarcoma [296], rhabdomyosarcoma [297] and medulloblastoma [298]. CP is given as a prodrug that undergoes extensive metabolism before it is converted to the active form (Figure 4). Upon entering the system, around $70 \%$ to $80 \%$ of $\mathrm{CP}$ is converted to 4-hydroxycyclophosphamide (4OHCP) [299], a reaction catalyzed mainly by CYP2B6 and to a lesser extent by 2C9, 2C19, 3A4 and 3A5 [300-302]. 4OHCP tautomerizes into aldophosphamide that spontaneously changes to phosphamide mustard (PM) and acrolein [299]. It is PM that exhibits DNA crosslinking properties and ultimately causes cytotoxicity. Acrolein is water soluble and clears out of the system via urine, due to its high toxicity can cause haemorrhagic cystitis and other ADRs [303]. 4OHCP and PM are cleared by glutathione S-transferase (GST), mainly GSTA1 and GSTP1 [304,305]. Aldehyde dehydrogenase (ALDH) 1 and ALDH2 enzymes were shown to convert aldophosphamide to non-toxic carboxyphosphamide. CP is also converted directly to 2-dechloroethylcyclophosphamide. Although this reaction represents around 10\% of total CP conversion, it is significant because it forms neurotoxic chloroacetaldehyde and is catalyzed by CYP3A4, CYP3A5 and CYP2B6 which is of concern when $\mathrm{CP}$ is used with other neurotoxic agents such as MTX or vincristine [302].

Current evidence for the involvement of CYPs, GSTs and ALDHs genetic variations in the pharmacokinetics of $\mathrm{CP}$ and $4 \mathrm{OHCP}$ is conflicting. A study by Erkhart et al. on 124 adults shows that variations in genes CYP2B6, CYP2C9, CYP2C19, CYP3A4, CYP3A5, GSTA1, GSTP1, ALDH1A1 and $A L D H 3 A 1$ do not explain the inter-individual variability in $\mathrm{CP}$ and $4 \mathrm{OHCP}$ pharmacokinetics [306]. Others, in contrast, found an association of these pharmacokinetic parameters with variations in CYP2B6 [307] and CYP2C19 genes [308]. A recent study reported a link between CYP2B6*6 allele and reduced $\mathrm{CP}$ clearance in children with B-cell non-Hodgkin's lymphoma [309]. Associations were also found between MTHFR and drug hematologic toxicity (aplasia, neutropenia, anemia and leukopenia) in children treated for osteosarcoma [188]. Other genes associated with cyclophosphamide efficacy and toxicity in adults include GSTP1 [213,214], super oxide dismutase 2 (SOD2) [215] and TP53 [151] but there is no report for these genes in children treated with CP. A particular problem when evaluating the genetic association of CP metabolism with CYPs, except for CYP2B6, is the ontogeny of CYPs in children at various developmental stages which changes the impact of variants. Additionally, $\mathrm{CP}$ is not used alone and most of the patients receive steroids at different doses, which are known to 
influence the expression of CYPs, and thus could alter the observations made in association studies. $\mathrm{CP}$ is used in different chemotherapy regimens at various dosing schedules and infusion times which can alter genotype-phenotype associations. The evidence reviewed here is of low to moderate and thus suggests that more comprehensive replication studies of $\mathrm{CP}$ are needed, especially in the field of pediatric oncology, before any clinical implementation would be possible.

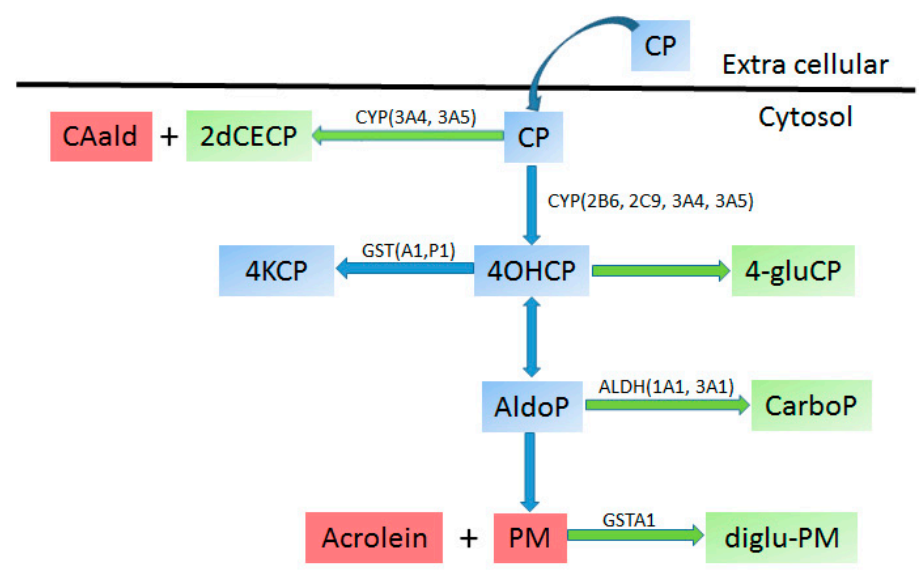

Figure 4. Metabolism of Cyclophophamide. Metabolites: Aldophoshphamide (AldoP), Chloroacetaldehyde (CAald), cyclophosphamide (CP), Carbophosphamide (CarboP), diglutathionylphosphoramide mustard (diglu-PM), Phosphoramide mustard (PM), 2-Dechloroethylcyclophosphamide (2dCECP), 4-Ketocyclophosphamide (4KCP). Enzymes: Cytochrome P450 3A4, 3A5, 2B6, 2C9 (CYP3A4, CYP3A5, CYP2B6, CYP2C9), Glutathione $S$-transferase alpha1, pi1 (GSTA1 GSTP1), Aldehyde dehydrogenase 1A1, 3A1 (ALDH1A1, ALDH3A1). Colors: blue-prodrug, drug; green-inactive metabolites, red-toxic metabolites (adapted from [22,299]).

\subsubsection{Irinotecan}

Irinotecan (IRT) is most extensively used in the treatment of metastatic colorectal cancer but in pediatric medicine it is primarily used to treat patients with Rhabdomyosarcomas and Ewing sarcoma [310]. IRT is a prodrug that is spontaneously converted to the active compound 7-ethyl-10-hydroxy-camptothecin (SN-38) by carboxylesterase (CES) 1 and CES2 (Figure 5). It is SN-38 that inhibits topoisomerase 1 complex causing irreparable double strand breaks in DNA forcing cells to arrest in S phase and eventually undergo cell death. The major metabolic pathway for ITR $(70 \%)$ involves uridine diphosphate (UDP) glucuronosyltransferase 1 (UGT1A1) enzyme that converts SN-38 into soluble and non-toxic SN-38 glucuronic acid excreted via the intestine. Other pathways for SN-38 clearance involve CYP3A4 and CYP3A5 oxidation that convert SN-38 into two inactive metabolites: APC (7-ethyl-10-[4-N-(5-aminopentanoic acid)-1-piperidino] carbonyloxycamptothecin) and NPC (7-ethyl-10-[4-(1-piperidino)-1-amino] carbonyloxycamptothecin), but the latter can be converted back to SN-38 by CES1 and CES2. Several transporters are involved in IRT transport: SLCO1B1, ABCB1, ABCC1, ABCC2 and ABCG2 [2,311]. Much like with other chemotherapeutics, overexposure of IRT can lead to ADRs such as myelosuppression, diarrhea and neutropenia [3,312]. Both UGT1A1 and CYP3A5 are well expressed in children and attain the adult level activity within 3-6 months post birth, hence genetic variants might predict the inter-individual variability to a large extent among children [313].

There are two variants with high frequency that both influence UGT1A1 expression. UGT1A1*28 is a thymine-adenine (TA) repetition in the promoter region affecting the ability of RNA polymerase to initiate gene expression [314]. Another is UGT1A1*6 that causes G71 to R substitution but was shown to modulate UGT1A1 activity through gene expression [315]. Unlike UGT1A1*28, UGT1A1*6 is more common in East Asian populations where the frequency of UGT1A1*28 is lower in comparison to Europeans or African Americans [316]. The extent of compiled evidence mainly in adults treated 
for various kinds of cancers for association of IRT and UGT1A1 persuaded several regulatory bodies including the FDA to issue a warning for $U G T 1 A 1^{*} 28$ poor metabolizers. The same was also done by The Royal Dutch Pharmacists Association-Pharmacogenetics Working Group [261] and French Groupe de Pharmacologie Clinique Oncologique (GPCO-Unicancer) and French Réseau National de Pharmacogénétique Hospitalière (RNPGx) [316], recommending to use lower doses of IRT in UGT1A1*28 poor metabolizers in order to avoid ADRs. In pediatric populations, variations in UGT1A1 showed no association with grade 3 and 4 neutropenia and diarrhea when used in low doses and in protracted protocol designed to avoid toxicity of irinotecan [249]. This is in agreement with a meta-analysis that reported association of UGT1A1 genetic variants with irinotecan clearance in patients receiving higher or medium doses but not lower doses [230]. Studies in children with neuroblastoma explored the association between IRT-related ADRs and UGT1A1, suggesting that UGT1A1*28 poor metabolizers could be at risk of ADRs [317,318].

Two genes identified through a genome wide association study (GWAS) showing strong association with IRT ADRs were semaphorin (SEMA) 3C and chromosome 8 open reading frame 34 (C8orf34) [216]. SEMA3C is a member of semaphorin family known to promote survival and tumorigenicity possibly through angiogenesis [319-321] while the function of C8orf34 is unknown. Although these two genes might present interesting new associations, no replication studies exist to corroborate these results, therefore, further exploration of their clinical validity is needed.

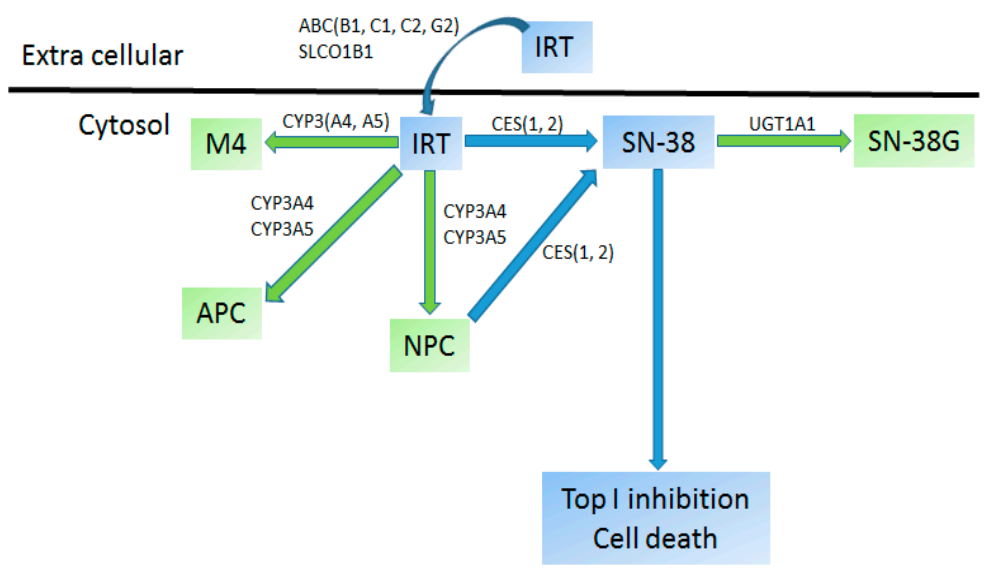

Figure 5. Metabolism of Irinotecan. Metabolites: Ethyl-10-[4- $N$-(5-aminopentanoic acid)-1-piperidino] carbonyloxycamptothecin (APC), Irinotecan (IRT), 7-ethyl-10-[4-(1-piperidino)-1-amino] carbonyloxycamptothecin (NPC), 7-Ethyl-10-hydroxy-camptothecin (SN-38), 7-Ethyl-10-hydroxycamptothecin glucoronic acid (SN-38G), Irinotecan metabolite M4 (M4). Enzymes: ATP binding cassette subfamily B1, C1, C2, G2 (ABCB1, ABCC1, ABCC2 and ABCG2), carboxylesterase 1, 2 (CES1, CES2), Cytochrome P450 3A4, 3A5 (CYP3A4, CYP3A5), Solute carrier organic anion transporter family member 1B1 (SLCO1B1), UDP glucuronosyltransferase family 1 member A1 (UGT1A1). Colors: blue-prodrug, drug or effect; green—inactive metabolites (adapted from [22]).

\subsubsection{Vincristine}

Vincristine is widely used as a combination chemotherapeutic agent for treating leukemias, lymphomas, brain tumors, neuroblastoma, Wilms tumor, rhabdomyosarcoma, Ewing sarcoma, and retinoblastoma in children [322]. Vincristine exert its cytotoxic effects by inhibiting microtubule formation thereby leading to mitotic arrest and cell death [323]. Approximately $25 \%$ of patients (both pediatric and adult) develop clinically significant vincristine-induced peripheral neuropathy (VIPN), necessitating the dose reduction or discontinuation of treatment [324]. CYP3A5 is predominantly involved in the metabolism of vincristine, and CYP3A5 is expressed only in $10 \%-20 \%$ of Caucasians $\left(\right.$ CYP3A $5 * 1 /{ }^{*} 1$ ) and more than $80 \%$ of African-Americans [325]. There are conflicting reports with majority of the studies favoring the association [324,326-329] of lower vincristine clearance in CYP3A5 
poor metabolizers with higher risk for VIPN. There are also some population differences observed for this association [330].

A recent genome wide association study in a prospective cohort identified a variant in centrosomal protein 72 (CEP72) gene associated with VIPN during continuation phase of ALL treatment with a high number of vincristine doses [331]. In the same study, authors experimentally showed that sensitivity to vincristine was improved with lower expression of CEP72. These findings raised a hope for safe vincristine dose prediction in ALL treatment protocols. However, another retrospective study during initiation phase of ALL treatment in Spanish children could not replicate this association [332], owing to differences in the study design, population and the stage of the treatment protocol. At our hospital, we also observed severe neuropathy in CYP3A5 poor metabolizers independent of CEP72 and $A B C B 1$ status [333]. The latter is a vincristine exporter protein, however, conflicting evidence of its association with treatment outcome in children with ALL exists [334-337].

Given that there is no difference in expression of CYP3A5 between adults and children, this finding might have clinical value for predicting vincristine induced neuropathy in children. However, because the level of evidence is low, replication studies with the higher level of evidence are needed to implement genotype testing combining CYP3A5, CEP72 and $A B C B 1$ for dose optimization of vincristine.

\section{Conclusions}

Upon reviewing the evidence gathered, sorted and published by PharmGKB (see Table 1), only the thiopurines/TPMT pair satisfies the highest standard of evidence needed for incorporation into clinical practice. Pediatric Pharmacogenomics recommendations for thiopurines do not differ from those used for adults. Particular attention should be paid to thiopurines/NUDT15 association which has shown consistent results in multiple studies and has a large effect. Although the associated variant has low allele frequency in European populations, its frequency is almost 10\% in East Asian populations (Table 1); resulting in a significant number of individuals with intermediate or poor metabolizing NUDT15 capacity. Cisplatin, the other drug in the group of strong evidence, was associated with XPC, but further association studies are clearly needed before the implementation into clinics. Moderate evidence gene-drug interactions were mostly produced for MTX pharmacogenetics. Studies are yet too few and hard to compare due to the variability across treatment protocols, diseases, populations and measurable outcomes. Irinotecan, on the other hand, has a strong association with UGT1A1 to the extent that, for example, Dutch and French guidelines suggest reducing the dose by $30 \%$ in cases of UGT1A1*28 poor metabolizers and are scheduled to receive more than $250 \mathrm{mg} / \mathrm{m}^{2}$ [261,316]. Also, there is a possibility to use the lowest dose and protracted protocols in order to avoid ADRs. However, as illustrated in Table 1, there is a clear lack of data for pediatric cohorts suggesting that this gene/drug pair might be most promising for immediate research efforts. Even though metabolism of CY includes many well-known pharmacogenes, such as CYPs, GSTs and ALDHs, association studies with pharmacokinetic produced conflicting data, thus showing the need to improve study designs to obtain conclusive results. Genes involved in oxidative stress response or genome stability affecting response to $\mathrm{CY}$ were classified as associations with moderate evidence, but have not yet been performed in children.

\section{Future Directions}

More systematic exploration of evidence based on prospective pediatric clinical trials is needed before any additional gene-drug interactions can be implemented in clinics. PharmGKB represents a valuable tool for clinicians and scientist for an overview and interpretation of the current data in pharmacogenomics. However, caution on interpretation of lower level gene-drug associations must be taken because the number of studies can vary substantially between gene-drug associations. A particular problem that the field of pediatric pharmacogenomic is faced with is ontology, which requires increased efforts to better understand the influence of genetic variants. Another problem 
facing future research is an increasing number of drug combinations used for treatment of cancer, which makes it harder to dissect the contribution of single therapeutic agents. A key for future research will be a better standardization of treatment regimens across multiple institutions and evaluation of genetic association in relation to complete treatment protocol.

Supplementary Materials: Supplementary materials can be found at www.mdpi.com/1422-0067/17/9/1502/s1.

Acknowledgments: This investigation was supported by a grant provided by CANSEARCH Foundation. Authors would like to thank the European Society of Pharmacogenomics and Personalised Therapy (ESPT) for support and organization of the Pediatric individualized treatment in oncology and hematology committee: Gerard Siest (In memory of Gérard Siest (9 April 2016) and his contribution to the science), Adrian Llerena, Ingolf Cascorbi, Janja Marc, Maurizio Simmaco, Peter Jacobs, Ron H.N. van Schaik, Sophie Visvikis-Siest and Vangelis G. Manolopoulos. Authors would also like to thank the following colleagues for their valuable discussion and suggestions: Ingolf Cascorbi, Natasa Karas Kuzelicki and Eva Choong.

Author Contributions: Vid Mlakar, Patricia Huezo-Diaz Curtis, Chakradhara Rao Satyanarayana Uppugunduri, Maja Krajinovic and Marc Ansari: wrote the manuscript and interpretation of data. Vid Mlakar, Patricia Huezo-Diaz Curtis and Marc Ansari: conception of the research, acquisition of data, preparation of tables and figures. Vid Mlakar, Patricia Huezo-Diaz Curtis, Chakradhara Rao Satyanarayana Uppugunduri, Maja Krajinovic and Marc Ansari: revised the manuscript critically.

Conflicts of Interest: The authors declare no conflict of interest.

\section{References}

1. Pritchard-Jones, K.; Dixon-Woods, M.; Naafs-Wilstra, M.; Valsecchi, M.G. Improving recruitment to clinical trials for cancer in childhood. Lancet Oncol. 2008, 9, 392-399. [CrossRef]

2. Mitchell, A.A.; Lacouture, P.G.; Sheehan, J.E.; Kauffman, R.E.; Shapiro, S. Adverse drug reactions in children leading to hospital admission. Pediatrics 1988, 82, 24-29. [PubMed]

3. MacNeil, M.; Eisenhauer, E.A. High-dose chemotherapy: Is it standard management for any common solid tumor? Ann. Oncol. 1999, 10, 1145-1161. [CrossRef] [PubMed]

4. Nebert, D.W. Pharmacogenetics and pharmacogenomics: Why is this relevant to the clinical geneticist? Clin. Genet. 1999, 56, 247-258. [CrossRef] [PubMed]

5. Stevens, A.; de Leonibus, C.; Hanson, D.; Whatmore, A.; Murray, P.; Donn, R.; Meyer, S.; Chatelain, P.; Clayton, P. Pediatric perspective on pharmacogenomics. Pharmacogenomics 2013, 14, 1889-1905. [CrossRef] [PubMed]

6. Holohan, C.; van Schaeybroeck, S.; Longley, D.B.; Johnston, P.G. Cancer drug resistance: An evolving paradigm. Nat. Rev. Cancer 2013, 13, 714-726. [CrossRef] [PubMed]

7. Longley, D.B.; Johnston, P.G. Molecular mechanisms of drug resistance. J. Pathol. 2005, 205, $275-292$. [CrossRef] [PubMed]

8. Bar-Shalom, D.; Rose, K. Pediatric Formulations: A Roadmap; AAPS Press/Springer: New York, NY, USA, 2014; Volume 11.

9. Kearns, G.L.; Abdel-Rahman, S.M.; Alander, S.W.; Blowey, D.L.; Leeder, J.S.; Kauffman, R.E. Developmental pharmacology-Drug disposition, action, and therapy in infants and children. N. Engl. J. Med. 2003, 349, 1157-1167. [PubMed]

10. Leeder, J.S.; Kearns, G.L. Pharmacogenetics in pediatrics. Implications for practice. Pediatr. Clin. N. Am. 1997, 44, 55-77. [CrossRef]

11. De Wildt, S.N.; Kearns, G.L.; Leeder, J.S.; van den Anker, J.N. Cytochrome P450 3A: Ontogeny and drug disposition. Clin. Pharmacokinet. 1999, 37, 485-505. [CrossRef] [PubMed]

12. Treluyer, J.M.; Jacqz-Aigrain, E.; Alvarez, F.; Cresteil, T. Expression of CYP2D6 in developing human liver. Eur. J. Biochem. 1991, 202, 583-588. [CrossRef] [PubMed]

13. Brouwer, K.L.; Aleksunes, L.M.; Brandys, B.; Giacoia, G.P.; Knipp, G.; Lukacova, V.; Meibohm, B.; Nigam, S.K.; Rieder, M.; de Wildt, S.N.; et al. Human Ontogeny of Drug Transporters: Review and Recommendations of the Pediatric Transporter Working Group. Clin. Pharmacol. Ther. 2015, 98, 266-287. [CrossRef] [PubMed]

14. Stevens, A.; Hanson, D.; Whatmore, A.; Destenaves, B.; Chatelain, P.; Clayton, P. Human growth is associated with distinct patterns of gene expression in evolutionarily conserved networks. BMC Genom. 2013, 14, 547. [CrossRef] [PubMed] 
15. Finkielstain, G.P.; Forcinito, P.; Lui, J.C.; Barnes, K.M.; Marino, R.; Makaroun, S.; Nguyen, V.; Lazarus, J.E.; Nilsson, O.; Baron, J. An extensive genetic program occurring during postnatal growth in multiple tissues. Endocrinology 2009, 150, 1791-1800. [CrossRef] [PubMed]

16. Knight, K.R.; Kraemer, D.F.; Neuwelt, E.A. Ototoxicity in children receiving platinum chemotherapy: Underestimating a commonly occurring toxicity that may influence academic and social development. J. Clin. Oncol. 2005, 23, 8588-8596. [CrossRef] [PubMed]

17. Kushner, B.H.; Budnick, A.; Kramer, K.; Modak, S.; Cheung, N.K. Ototoxicity from high-dose use of platinum compounds in patients with neuroblastoma. Cancer 2006, 107, 417-422. [CrossRef] [PubMed]

18. Bleyer, W.A.; Fallavollita, J.; Robison, L.; Balsom, W.; Meadows, A.; Heyn, R.; Sitarz, A.; Ortega, J.; Miller, D.; Constine, L.; et al. Influence of age, sex, and concurrent intrathecal methotrexate therapy on intellectual function after cranial irradiation during childhood: A report from the Children's Cancer Study Group. Pediatr. Hematol. Oncol. 1990, 7, 329-338. [CrossRef] [PubMed]

19. Lazaryan, M.; Shasha-Zigelman, C.; Dagan, Z.; Berkovitch, M. Codeine should not be prescribed for breastfeeding mothers or children under the age of 12. Acta Paediatr. 2015, 104, 550-556. [CrossRef] [PubMed]

20. Uppugunduri, C.R.; Ansari, M. Commentary: A myriad aberrations on information of ontogeny of drug metabolizing enzymes in the pediatric population: An obstacle for personalizing drug therapy in the pediatric population. Drug Metab. Lett. 2016, 10, 72-74. [CrossRef] [PubMed]

21. Perry, M.C.; Doll, D.C.; Freter, C.E. Chemotherapy Source Book, 5th ed.; Wolters Kluwer/Lippincott Williams \& Wilkins: Philadelphia, PA, USA, 2012.

22. Whirl-Carrillo, M.; McDonagh, E.M.; Hebert, J.M.; Gong, L.; Sangkuhl, K.; Thorn, C.F.; Altman, R.B.; Klein, T.E. Pharmacogenomics knowledge for personalized medicine. Clin. Pharmacol. Ther. 2012, 92, 414-417. [CrossRef] [PubMed]

23. Aghdaie, M.H.; Azarpira, N.; Geramizadeh, B.; Sagheb, M.; Darai, M.; Rahsaz, M.; Malekhoseini, S.A. Thiopurine S-methyltransferase polymorphism in Iranian kidney transplant recipients. Exp. Clin. Transplant. 2011, 9, 241-246. [PubMed]

24. Alves, S.; Amorim, A.; Ferreira, F.; Prata, M.J. Influence of the variable number of tandem repeats located in the promoter region of the thiopurine methyltransferase gene on enzymatic activity. Clin. Pharmacol. Ther. 2001, 70, 165-174. [CrossRef] [PubMed]

25. Alves, S.; Prata, M.J.; Ferreira, F.; Amorim, A. Thiopurine methyltransferase pharmacogenetics: Alternative molecular diagnosis and preliminary data from Northern Portugal. Pharmacogenetics 1999, 9, 257-261. [PubMed]

26. Ansari, A.; Arenas, M.; Greenfield, S.M.; Morris, D.; Lindsay, J.; Gilshenan, K.; Smith, M.; Lewis, C.; Marinaki, A.; Duley, J.; et al. Prospective evaluation of the pharmacogenetics of azathioprine in the treatment of inflammatory bowel disease. Aliment. Pharmacol. Ther. 2008, 28, 973-983. [CrossRef] [PubMed]

27. Ansari, A.; Hassan, C.; Duley, J.; Marinaki, A.; Shobowale-Bakre, E.M.; Seed, P.; Meenan, J.; Yim, A.; Sanderson, J. Thiopurine methyltransferase activity and the use of azathioprine in inflammatory bowel disease. Aliment. Pharmacol. Ther. 2002, 16, 1743-1750. [CrossRef] [PubMed]

28. Ban, H.; Andoh, A.; Tanaka, A.; Tsujikawa, T.; Sasaki, M.; Saito, Y.; Fujiyama, Y. Analysis of thiopurine $S$-methyltransferase genotypes in Japanese patients with inflammatory bowel disease. Intern. Med. 2008, 47, 1645-1648. [CrossRef] [PubMed]

29. Black, A.J.; McLeod, H.L.; Capell, H.A.; Powrie, R.H.; Matowe, L.K.; Pritchard, S.C.; Collie-Duguid, E.S.; Reid, D.M. Thiopurine methyltransferase genotype predicts therapy-limiting severe toxicity from azathioprine. Ann. Intern. Med. 1998, 129, 716-718. [CrossRef] [PubMed]

30. Breen, D.P.; Marinaki, A.M.; Arenas, M.; Hayes, P.C. Pharmacogenetic association with adverse drug reactions to azathioprine immunosuppressive therapy following liver transplantation. Liver Transpl. 2005, 11, 826-833. [CrossRef] [PubMed]

31. Budhiraja, P.; Popovtzer, M. Azathioprine-related myelosuppression in a patient homozygous for TPMT*3A. Nat. Rev. Nephrol. 2011, 7, 478-484. [CrossRef] [PubMed]

32. Cheung, S.T.; Allan, R.N. Mistaken identity: Misclassification of TPMT phenotype following blood transfusion. Eur. J. Gastroenterol. Hepatol. 2003, 15, 1245-1247. [CrossRef] [PubMed] 
33. Chrzanowska, M.; Kurzawski, M.; Drozdzik, M.; Mazik, M.; Oko, A.; Czekalski, S. Thiopurine S-methyltransferase phenotype-genotype correlation in hemodialyzed patients. Pharmacol. Rep. 2006, 58, 973-978. [PubMed]

34. Corominas, H.; Domenech, M.; Laiz, A.; Gich, I.; Geli, C.; Diaz, C.; de Cuevillas, F.; Moreno, M.; Vazquez, G.; Baiget, M. Is thiopurine methyltransferase genetic polymorphism a major factor for withdrawal of azathioprine in rheumatoid arthritis patients? Rheumatology (Oxford) 2003, 42, 40-45. [CrossRef] [PubMed]

35. Dong, X.W.; Zheng, Q.; Zhu, M.M.; Tong, J.L.; Ran, Z.H. Thiopurine S-methyltransferase polymorphisms and thiopurine toxicity in treatment of inflammatory bowel disease. World J. Gastroenterol. 2010, 16, 3187-3195. [CrossRef] [PubMed]

36. El-Sedfy, A.; Chamberlain, R.S. Surgeons and their tools: A history of surgical instruments and their innovators-Part I: Place the scissors on the Mayo stand. Am. Surg. 2014, 80, 1089-1092. [PubMed]

37. Fabre, M.A.; Jones, D.C.; Bunce, M.; Morris, P.J.; Friend, P.J.; Welsh, K.I.; Marshall, S.E. The impact of thiopurine $S$-methyltransferase polymorphisms on azathioprine dose 1 year after renal transplantation. Transpl. Int. 2004, 17, 531-539. [CrossRef] [PubMed]

38. Formea, C.M.; Myers-Huentelman, H.; Wu, R.; Crabtree, J.; Fujita, S.; Hemming, A.; Reed, A.; Howard, R.; Karlix, J.L. Thiopurine $S$-methyltransferase genotype predicts azathioprine-induced myelotoxicity in kidney transplant recipients. Am. J. Transplant. 2004, 4, 1810-1817. [CrossRef] [PubMed]

39. Gardiner, S.J.; Gearry, R.B.; Begg, E.J.; Zhang, M.; Barclay, M.L. Thiopurine dose in intermediate and normal metabolizers of thiopurine methyltransferase may differ three-fold. Clin. Gastroenterol. Hepatol. 2008, 6, 654-660. [CrossRef] [PubMed]

40. Gearry, R.B.; Barclay, M.L.; Roberts, R.L.; Harraway, J.; Zhang, M.; Pike, L.S.; George, P.M.; Florkowski, C.M. Thiopurine methyltransferase and 6-thioguanine nucleotide measurement: Early experience of use in clinical practice. Intern. Med. J. 2005, 35, 580-585. [CrossRef] [PubMed]

41. Haglund, S.; Lindqvist, M.; Almer, S.; Peterson, C.; Taipalensuu, J. Pyrosequencing of TPMT alleles in a general Swedish population and in patients with inflammatory bowel disease. Clin. Chem. 2004, 50, 288-295. [CrossRef] [PubMed]

42. Heckmann, J.M.; Lambson, E.M.; Little, F.; Owen, E.P. Thiopurine methyltransferase (TPMT) heterozygosity and enzyme activity as predictive tests for the development of azathioprine-related adverse events. J. Neurol. Sci. 2005, 231, 71-80. [CrossRef] [PubMed]

43. Higgs, J.E.; Payne, K.; Roberts, C.; Newman, W.G. Are patients with intermediate TPMT activity at increased risk of myelosuppression when taking thiopurine medications? Pharmacogenomics 2010, 11, 177-188. [CrossRef] [PubMed]

44. Hindorf, U.; Lindqvist, M.; Peterson, C.; Soderkvist, P.; Strom, M.; Hjortswang, H.; Pousette, A.; Almer, S. Pharmacogenetics during standardised initiation of thiopurine treatment in inflammatory bowel disease. Gut 2006, 55, 1423-1431. [CrossRef] [PubMed]

45. Hindorf, U.; Lyrenas, E.; Nilsson, A.; Schmiegelow, K. Monitoring of long-term thiopurine therapy among adults with inflammatory bowel disease. Scand. J. Gastroenterol. 2004, 39, 1105-1112. [CrossRef] [PubMed]

46. Hon, Y.Y.; Fessing, M.Y.; Pui, C.H.; Relling, M.V.; Krynetski, E.Y.; Evans, W.E. Polymorphism of the thiopurine S-methyltransferase gene in African-Americans. Hum. Mol. Genet. 1999, 8, 371-376. [CrossRef] [PubMed]

47. Indjova, D.; Atanasova, S.; Shipkova, M.; Armstrong, V.W.; Oellerich, M.; Svinarov, D. Phenotypic and genotypic analysis of thiopurine $S$-methyltransferase polymorphism in the bulgarian population. Ther. Drug Monit. 2003, 25, 631-636. [CrossRef] [PubMed]

48. Jun, J.B.; Cho, D.Y.; Kang, C.; Bae, S.C. Thiopurine S-methyltransferase polymorphisms and the relationship between the mutant alleles and the adverse effects in systemic lupus erythematosus patients taking azathioprine. Clin. Exp. Rheumatol. 2005, 23, 873-876. [PubMed]

49. Kaskas, B.A.; Louis, E.; Hindorf, U.; Schaeffeler, E.; Deflandre, J.; Graepler, F.; Schmiegelow, K.; Gregor, M.; Zanger, U.M.; Eichelbaum, M.; et al. Safe treatment of thiopurine $S$-methyltransferase deficient Crohn's disease patients with azathioprine. Gut 2003, 52, 140-142. [CrossRef] [PubMed]

50. Kim, J.H.; Cheon, J.H.; Hong, S.S.; Eun, C.S.; Byeon, J.S.; Hong, S.Y.; Kim, B.Y.; Kwon, S.H.; Kim, S.W.; Han, D.S.; et al. Influences of thiopurine methyltransferase genotype and activity on thiopurine-induced leukopenia in Korean patients with inflammatory bowel disease: A retrospective cohort study. J. Clin. Gastroenterol. 2010, 44, e242-e248. [CrossRef] [PubMed] 
51. Krynetski, E.Y.; Schuetz, J.D.; Galpin, A.J.; Pui, C.H.; Relling, M.V.; Evans, W.E. A single point mutation leading to loss of catalytic activity in human thiopurine S-methyltransferase. Proc. Natl. Acad. Sci. USA 1995, 92, 949-953. [CrossRef] [PubMed]

52. Kurzawski, M.; Dziewanowski, K.; Gawronska-Szklarz, B.; Domanski, L.; Drozdzik, M. The impact of thiopurine $S$-methyltransferase polymorphism on azathioprine-induced myelotoxicity in renal transplant recipients. Ther. Drug Monit. 2005, 27, 435-441. [CrossRef] [PubMed]

53. Landy, J.; Bhuva, N.; Marinaki, A.; Mawdsley, J. Novel thiopurine methyltransferase variant TPMT*28 results in a misdiagnosis of TPMT deficiency. Inflamm. Bowel Dis. 2011, 17, 1441-1442. [CrossRef] [PubMed]

54. Larovere, L.E.; de Kremer, R.D.; Lambooy, L.H.; De Abreu, R.A. Genetic polymorphism of thiopurine S-methyltransferase in Argentina. Ann. Clin. Biochem. 2003, 40, 388-393. [CrossRef] [PubMed]

55. Lindqvist, M.; Haglund, S.; Almer, S.; Peterson, C.; Taipalensu, J.; Hertervig, E.; Lyrenas, E.; Soderkvist, P. Identification of two novel sequence variants affecting thiopurine methyltransferase enzyme activity. Pharmacogenetics 2004, 14, 261-265. [CrossRef] [PubMed]

56. Lindqvist, M.; Skoglund, K.; Karlgren, A.; Soderkvist, P.; Peterson, C.; Kidhall, I.; Almer, S. Explaining TPMT genotype/phenotype discrepancy by haplotyping of TPMT*3A and identification of a novel sequence variant, TPMT*23. Pharmacogenet. Genom. 2007, 17, 891-895. [CrossRef] [PubMed]

57. Loennechen, T.; Yates, C.R.; Fessing, M.Y.; Relling, M.V.; Krynetski, E.Y.; Evans, W.E. Isolation of a human thiopurine $S$-methyltransferase (TPMT) complementary DNA with a single nucleotide transition A719G (TPMT*3C) and its association with loss of TPMT protein and catalytic activity in humans. Clin. Pharmacol. Ther. 1998, 64, 46-51. [CrossRef]

58. Milek, M.; Murn, J.; Jaksic, Z.; Lukac Bajalo, J.; Jazbec, J.; Mlinaric Rascan, I. Thiopurine S-methyltransferase pharmacogenetics: Genotype to phenotype correlation in the Slovenian population. Pharmacology 2006, 77, 105-114. [CrossRef] [PubMed]

59. Moloney, F.J.; Dicker, P.; Conlon, P.J.; Shields, D.C.; Murphy, G.M. The frequency and significance of thiopurine $S$-methyltransferase gene polymorphisms in azathioprine-treated renal transplant recipients. Br. J. Dermatol. 2006, 154, 1199-1200. [CrossRef] [PubMed]

60. Newman, W.G.; Payne, K.; Tricker, K.; Roberts, S.A.; Fargher, E.; Pushpakom, S.; Alder, J.E.; Sidgwick, G.P.; Payne, D.; Elliott, R.A.; et al. A pragmatic randomized controlled trial of thiopurine methyltransferase genotyping prior to azathioprine treatment: The TARGET study. Pharmacogenomics 2011, 12, 815-826. [CrossRef] [PubMed]

61. Ogungbenro, K.; Aarons, L.; Cresim; Epi, C.P.G. Physiologically based pharmacokinetic model for 6-mercpatopurine: Exploring the role of genetic polymorphism in TPMT enzyme activity. $\mathrm{Br} . \quad \mathrm{J}$. Clin. Pharmacol. 2015, 80, 86-100. [CrossRef] [PubMed]

62. Okada, Y.; Nakamura, K.; Kodama, T.; Ueki, K.; Tsukada, Y.; Maezawa, A.; Tsukamoto, N.; Nojima, Y.; Ishizaki, T.; Horiuchi, R.; et al. Thiopurine methyltransferase genotype and phenotype status in Japanese patients with systemic lupus erythematosus. Biol. Pharm. Bull. 2005, 28, 2117-2119. [CrossRef] [PubMed]

63. Otterness, D.; Szumlanski, C.; Lennard, L.; Klemetsdal, B.; Aarbakke, J.; Park-Hah, J.O.; Iven, H.; Schmiegelow, K.; Branum, E.; O’Brien, J.; et al. Human thiopurine methyltransferase pharmacogenetics: Gene sequence polymorphisms. Clin. Pharmacol. Ther. 1997, 62, 60-73. [CrossRef]

64. Otterness, D.M.; Szumlanski, C.L.; Wood, T.C.; Weinshilboum, R.M. Human thiopurine methyltransferase pharmacogenetics. Kindred with a terminal exon splice junction mutation that results in loss of activity. J. Clin. Investig. 1998, 101, 1036-1044. [CrossRef] [PubMed]

65. Reis, M.; Santoro, A.; Suarez-Kurtz, G. Thiopurine methyltransferase phenotypes and genotypes in Brazilians. Pharmacogenetics 2003, 13, 371-373. [CrossRef] [PubMed]

66. Rossi, A.M.; Bianchi, M.; Guarnieri, C.; Barale, R.; Pacifici, G.M. Genotype-phenotype correlation for thiopurine S-methyltransferase in healthy Italian subjects. Eur. J. Clin. Pharmacol. 2001, 57, 51-54. [CrossRef] [PubMed]

67. Salavaggione, O.E.; Wang, L.; Wiepert, M.; Yee, V.C.; Weinshilboum, R.M. Thiopurine S-methyltransferase pharmacogenetics: Variant allele functional and comparative genomics. Pharmacogenet. Genom. 2005, 15, 801-815. [CrossRef]

68. Samochatova, E.V.; Chupova, N.V.; Rudneva, A.; Makarova, O.; Nasedkina, T.V.; Fedorova, O.E.; Glotov, A.S.; Kozhekbaeva, Z.; Maiorova, O.A.; Roumyantsev, A.G.; et al. TPMT genetic variations in populations of the Russian Federation. Pediatr. Blood Cancer 2009, 52, 203-208. [CrossRef] [PubMed] 
69. Schaeffeler, E.; Fischer, C.; Brockmeier, D.; Wernet, D.; Moerike, K.; Eichelbaum, M.; Zanger, U.M.; Schwab, M. Comprehensive analysis of thiopurine $S$-methyltransferase phenotype-genotype correlation in a large population of German-Caucasians and identification of novel TPMT variants. Pharmacogenetics 2004, 14, 407-417. [CrossRef] [PubMed]

70. Schwab, M.; Schaffeler, E.; Marx, C.; Fischer, C.; Lang, T.; Behrens, C.; Gregor, M.; Eichelbaum, M.; Zanger, U.M.; Kaskas, B.A. Azathioprine therapy and adverse drug reactions in patients with inflammatory bowel disease: Impact of thiopurine S-methyltransferase polymorphism. Pharmacogenetics 2002, 12, 429-436. [CrossRef] [PubMed]

71. Sebbag, L.; Boucher, P.; Davelu, P.; Boissonnat, P.; Champsaur, G.; Ninet, J.; Dureau, G.; Obadia, J.F.; Vallon, J.J.; Delaye, J. Thiopurine $S$-methyltransferase gene polymorphism is predictive of azathioprine-induced myelosuppression in heart transplant recipients. Transplantation 2000, 69, 1524-1527. [CrossRef] [PubMed]

72. Serpe, L.; Calvo, P.L.; Muntoni, E.; D'Antico, S.; Giaccone, M.; Avagnina, A.; Baldi, M.; Barbera, C.; Curti, F.; Pera, A.; et al. Thiopurine $S$-methyltransferase pharmacogenetics in a large-scale healthy Italian-Caucasian population: Differences in enzyme activity. Pharmacogenomics 2009, 10, 1753-1765. [CrossRef] [PubMed]

73. Song, D.K.; Zhao, J.; Zhang, L.R. TPMT genotype and its clinical implication in renal transplant recipients with azathioprine treatment. J. Clin. Pharm. Ther. 2006, 31, 627-635. [CrossRef] [PubMed]

74. De la Moureyre, C.S.V.; Debuysere, H.; Sabbagh, N.; Marez, D.; Vinner, E.; Chevalier, E.D.; Lo Guidice, J.M.; Broly, F. Detection of known and new mutations in the thiopurine $S$-methyltransferase gene by single-strand conformation polymorphism analysis. Hum. Mutat. 1998, 12, 177-185. [CrossRef]

75. Tai, H.L.; Fessing, M.Y.; Bonten, E.J.; Yanishevsky, Y.; d'Azzo, A.; Krynetski, E.Y.; Evans, W.E. Enhanced proteasomal degradation of mutant human thiopurine $S$-methyltransferase (TPMT) in mammalian cells: Mechanism for TPMT protein deficiency inherited by TPMT*2, TPMT*3A, TPMT*3B or TPMT*3C. Pharmacogenetics 1999, 9, 641-650. [CrossRef] [PubMed]

76. Tai, H.L.; Krynetski, E.Y.; Schuetz, E.G.; Yanishevski, Y.; Evans, W.E. Enhanced proteolysis of thiopurine $S$-methyltransferase (TPMT) encoded by mutant alleles in humans (TPMT*3A, TPMT*2): Mechanisms for the genetic polymorphism of TPMT activity. Proc. Natl. Acad. Sci. USA 1997, 94, 6444-6449. [CrossRef] [PubMed]

77. Tai, H.L.; Krynetski, E.Y.; Yates, C.R.; Loennechen, T.; Fessing, M.Y.; Krynetskaia, N.F.; Evans, W.E. Thiopurine $S$-methyltransferase deficiency: Two nucleotide transitions define the most prevalent mutant allele associated with loss of catalytic activity in Caucasians. Am. J. Hum. Genet. 1996, 58, 694-702. [PubMed]

78. Taja-Chayeb, L.; Vidal-Millan, S.; Gutierrez, O.; Ostrosky-Wegman, P.; Duenas-Gonzalez, A.; Candelaria, M. Thiopurine $S$-methyltransferase gene (TMPT) polymorphisms in a Mexican population of healthy individuals and leukemic patients. Med. Oncol. 2008, 25, 56-62. [CrossRef] [PubMed]

79. Takatsu, N.; Matsui, T.; Murakami, Y.; Ishihara, H.; Hisabe, T.; Nagahama, T.; Maki, S.; Beppu, T.; Takaki, Y.; Hirai, F.; et al. Adverse reactions to azathioprine cannot be predicted by thiopurine $S$-methyltransferase genotype in Japanese patients with inflammatory bowel disease. J. Gastroenterol. Hepatol. 2009, 24, 1258-1264. [CrossRef] [PubMed]

80. Tamm, R.; Oselin, K.; Kallassalu, K.; Magi, R.; Anier, K.; Remm, M.; Metspalu, A. Thiopurine $S$-methyltransferase (TPMT) pharmacogenetics: Three new mutations and haplotype analysis in the Estonian population. Clin. Chem. Lab. Med. 2008, 46, 974-979. [CrossRef] [PubMed]

81. Tamori, A.; Shinzaki, M.; Kosaka, S.; Hayashi, T.; Iwai, S.; Enomoto, M.; Habu, D.; Sakaguchi, H.; Kawada, N.; Hino, M.; et al. Thiopurine $S$-methyltransferase gene polymorphism in Japanese patients with autoimmune liver diseases. Liver Int. 2007, 27, 95-100. [CrossRef] [PubMed]

82. Ujiie, S.; Sasaki, T.; Mizugaki, M.; Ishikawa, M.; Hiratsuka, M. Functional characterization of 23 allelic variants of thiopurine $S$-methyltransferase gene (TPMT*2-*24). Pharmacogenet. Genom. 2008, 18, 887-893. [CrossRef] [PubMed]

83. Vannaprasaht, S.; Angsuthum, S.; Avihingsanon, Y.; Sirivongs, D.; Pongskul, C.; Makarawate, P.; Praditpornsilpa, K.; Tassaneeyakul, W.; Tassaneeyakul, W. Impact of the heterozygous TPMT*1/*3C genotype on azathioprine-induced myelosuppression in kidney transplant recipients in Thailand. Clin. Ther. 2009, 31, 1524-1533. [CrossRef] [PubMed] 
84. Winter, J.W.; Gaffney, D.; Shapiro, D.; Spooner, R.J.; Marinaki, A.M.; Sanderson, J.D.; Mills, P.R. Assessment of thiopurine methyltransferase enzyme activity is superior to genotype in predicting myelosuppression following azathioprine therapy in patients with inflammatory bowel disease. Aliment. Pharmacol. Ther. 2007, 25, 1069-1077. [CrossRef] [PubMed]

85. Xin, H.W.; Xiong, H.; Wu, X.C.; Li, Q.; Xiong, L.; Yu, A.R. Relationships between thiopurine $S$-methyltransferase polymorphism and azathioprine-related adverse drug reactions in Chinese renal transplant recipients. Eur. J. Clin. Pharmacol. 2009, 65, 249-255. [CrossRef] [PubMed]

86. Yates, C.R.; Krynetski, E.Y.; Loennechen, T.; Fessing, M.Y.; Tai, H.L.; Pui, C.H.; Relling, M.V.; Evans, W.E. Molecular diagnosis of thiopurine $S$-methyltransferase deficiency: Genetic basis for azathioprine and mercaptopurine intolerance. Ann. Intern. Med. 1997, 126, 608-614. [CrossRef] [PubMed]

87. Zelinkova, Z.; Derijks, L.J.; Stokkers, P.C.; Vogels, E.W.; van Kampen, A.H.; Curvers, W.L.; Cohn, D.; van Deventer, S.J.; Hommes, D.W. Inosine triphosphate pyrophosphatase and thiopurine $S$-methyltransferase genotypes relationship to azathioprine-induced myelosuppression. Clin. Gastroenterol. Hepatol. 2006, 4, 44-49. [CrossRef] [PubMed]

88. Zhang, L.R.; Song, D.K.; Zhang, W.; Zhao, J.; Jia, L.J.; Xing, D.L. Efficient screening method of the thiopurine methyltransferase polymorphisms for patients considering taking thiopurine drugs in a Chinese Han population in Henan Province (central China). Clin. Chim. Acta 2007, 376, 45-51. [CrossRef] [PubMed]

89. Adam de Beaumais, T.; Fakhoury, M.; Medard, Y.; Azougagh, S.; Zhang, D.; Yakouben, K.; Jacqz-Aigrain, E. Determinants of mercaptopurine toxicity in paediatric acute lymphoblastic leukemia maintenance therapy. Br. J. Clin. Pharmacol. 2011, 71, 575-584. [CrossRef] [PubMed]

90. Andersen, J.B.; Szumlanski, C.; Weinshilboum, R.M.; Schmiegelow, K. Pharmacokinetics, dose adjustments, and 6-mercaptopurine/methotrexate drug interactions in two patients with thiopurine methyltransferase deficiency. Acta Paediatr. 1998, 87, 108-111. [CrossRef] [PubMed]

91. Ando, M.; Ando, Y.; Hasegawa, Y.; Sekido, Y.; Shimokata, K.; Horibe, K. Genetic polymorphisms of thiopurine $S$-methyltransferase and 6-mercaptopurine toxicity in Japanese children with acute lymphoblastic leukaemia. Pharmacogenetics 2001, 11, 269-273. [CrossRef] [PubMed]

92. De Ridder, L.; Van Dieren, J.M.; Van Deventer, H.J.; Stokkers, P.C.; Van der Woude, J.C.; Van Vuuren, A.J.; Benninga, M.A.; Escher, J.C.; Hommes, D.W. Pharmacogenetics of thiopurine therapy in paediatric IBD patients. Aliment. Pharmacol. Ther. 2006, 23, 1137-1141. [CrossRef] [PubMed]

93. Dokmanovic, L.; Urosevic, J.; Janic, D.; Jovanovic, N.; Petrucev, B.; Tosic, N.; Pavlovic, S. Analysis of thiopurine $S$-methyltransferase polymorphism in the population of Serbia and Montenegro and mercaptopurine therapy tolerance in childhood acute lymphoblastic leukemia. Ther. Drug Monit. 2006, 28, 800-806. [CrossRef] [PubMed]

94. Dubinsky, M.C.; Lamothe, S.; Yang, H.Y.; Targan, S.R.; Sinnett, D.; Theoret, Y.; Seidman, E.G. Pharmacogenomics and metabolite measurement for 6-mercaptopurine therapy in inflammatory bowel disease. Gastroenterology 2000, 118, 705-713. [CrossRef]

95. Evans, W.E.; Horner, M.; Chu, Y.Q.; Kalwinsky, D.; Roberts, W.M. Altered mercaptopurine metabolism, toxic effects, and dosage requirement in a thiopurine methyltransferase-deficient child with acute lymphocytic leukemia. J. Pediatr. 1991, 119, 985-989. [CrossRef]

96. Ganiere-Monteil, C.; Medard, Y.; Lejus, C.; Bruneau, B.; Pineau, A.; Fenneteau, O.; Bourin, M.; Jacqz-Aigrain, E. Phenotype and genotype for thiopurine methyltransferase activity in the French Caucasian population: Impact of age. Eur. J. Clin. Pharmacol. 2004, 60, 89-96. [PubMed]

97. Gazouli, M.; Pachoula, I.; Panayotou, I.; Mantzaris, G.; Syriopoulou, V.P.; Goutas, N.; Vlachodimitropoulos, D.; Anagnou, N.P.; Roma-Giannikou, E. Thiopurine S-methyltransferase genotype and the use of thiopurines in paediatric inflammatory bowel disease Greek patients. J. Clin. Pharm. Ther. 2010, 35, 93-97. [CrossRef] [PubMed]

98. Hindorf, U.; Peterson, C.; Almer, S. Assessment of thiopurine methyltransferase and metabolite formation during thiopurine therapy: Results from a large Swedish patient population. Ther. Drug Monit. 2004, 26, 673-678. [CrossRef] [PubMed]

99. Kapoor, G.; Sinha, R.; Naithani, R.; Chandgothia, M. Thiopurine S-methyltransferase gene polymorphism and 6-mercaptopurine dose intensity in Indian children with acute lymphoblastic leukemia. Leuk. Res. 2010, 34, 1023-1026. [CrossRef] [PubMed] 
100. Karas-Kuzelicki, N.; Jazbec, J.; Milek, M.; Mlinaric-Rascan, I. Heterozygosity at the TPMT gene locus, augmented by mutated MTHFR gene, predisposes to 6-MP related toxicities in childhood ALL patients. Leukemia 2009, 23, 971-974. [CrossRef] [PubMed]

101. Kham, S.K.; Tan, P.L.; Tay, A.H.; Heng, C.K.; Yeoh, A.E.; Quah, T.C. Thiopurine methyltransferase polymorphisms in a multiracial asian population and children with acute lymphoblastic leukemia. J. Pediatr. Hematol. Oncol. 2002, 24, 353-359. [CrossRef] [PubMed]

102. Kim, H.; Kang, H.J.; Kim, H.J.; Jang, M.K.; Kim, N.H.; Oh, Y.; Han, B.D.; Choi, J.Y.; Kim, C.W.; Lee, J.W.; et al. Pharmacogenetic analysis of pediatric patients with acute lymphoblastic leukemia: A possible association between survival rate and ITPA polymorphism. PLoS ONE 2012, 7, e45558. [CrossRef] [PubMed]

103. Lennard, L.; Cartwright, C.S.; Wade, R.; Richards, S.M.; Vora, A. Thiopurine methyltransferase genotype-phenotype discordance and thiopurine active metabolite formation in childhood acute lymphoblastic leukaemia. Br. J. Clin. Pharmacol. 2013, 76, 125-136. [CrossRef] [PubMed]

104. Lennard, L.; Cartwright, C.S.; Wade, R.; Vora, A. Thiopurine dose intensity and treatment outcome in childhood lymphoblastic leukaemia: The influence of thiopurine methyltransferase pharmacogenetics. Br. J. Haematol. 2015, 169, 228-240. [CrossRef] [PubMed]

105. Lennard, L.; Gibson, B.E.; Nicole, T.; Lilleyman, J.S. Congenital thiopurine methyltransferase deficiency and 6-mercaptopurine toxicity during treatment for acute lymphoblastic leukaemia. Arch. Dis. Child. 1993, 69, 577-579. [CrossRef] [PubMed]

106. Lennard, L.; Richards, S.; Cartwright, C.S.; Mitchell, C.; Lilleyman, J.S.; Vora, A. The thiopurine methyltransferase genetic polymorphism is associated with thioguanine-related veno-occlusive disease of the liver in children with acute lymphoblastic leukemia. Clin. Pharmacol. Ther. 2006, 80, 375-383. [CrossRef] [PubMed]

107. Levinsen, M.; Rosthoj, S.; Nygaard, U.; Heldrup, J.; Harila-Saari, A.; Jonsson, O.G.; Bechensteen, A.G.; Abrahamsson, J.; Lausen, B.; Frandsen, T.L.; et al. Myelotoxicity after high-dose methotrexate in childhood acute leukemia is influenced by 6-mercaptopurine dosing but not by intermediate thiopurine methyltransferase activity. Cancer Chemother. Pharmacol. 2015, 75, 59-66. [CrossRef] [PubMed]

108. McBride, K.L.; Gilchrist, G.S.; Smithson, W.A.; Weinshilboum, R.M.; Szumlanski, C.L. Severe 6-thioguanine-induced marrow aplasia in a child with acute lymphoblastic leukemia and inherited thiopurine methyltransferase deficiency. J. Pediatr. Hematol. Oncol. 2000, 22, 441-445. [CrossRef] [PubMed]

109. McLeod, H.L.; Coulthard, S.; Thomas, A.E.; Pritchard, S.C.; King, D.J.; Richards, S.M.; Eden, O.B.; Hall, A.G.; Gibson, B.E. Analysis of thiopurine methyltransferase variant alleles in childhood acute lymphoblastic leukaemia. Br. J. Haematol. 1999, 105, 696-700. [CrossRef] [PubMed]

110. Peregud-Pogorzelski, J.; Tetera-Rudnicka, E.; Kurzawski, M.; Brodkiewicz, A.; Adrianowska, N.; Mlynarski, W.; Januszkiewicz, D.; Drozdzik, M. Thiopurine S-methyltransferase (TPMT) polymorphisms in children with acute lymphoblastic leukemia, and the need for reduction or cessation of 6-mercaptopurine doses during maintenance therapy: The Polish multicenter analysis. Pediatr. Blood Cancer 2011, 57, 578-582. [CrossRef] [PubMed]

111. Relling, M.V.; Hancock, M.L.; Rivera, G.K.; Sandlund, J.T.; Ribeiro, R.C.; Krynetski, E.Y.; Pui, C.H.; Evans, W.E. Mercaptopurine therapy intolerance and heterozygosity at the thiopurine $S$-methyltransferase gene locus. J. Natl. Cancer Inst. 1999, 91, 2001-2008. [CrossRef] [PubMed]

112. Schaeffeler, E.; Stanulla, M.; Greil, J.; Schrappe, M.; Eichelbaum, M.; Zanger, U.M.; Schwab, M. A novel TPMT missense mutation associated with TPMT deficiency in a 5-year-old boy with ALL. Leukemia 2003, 17, 1422-1424. [CrossRef] [PubMed]

113. Schmiegelow, K.; Forestier, E.; Kristinsson, J.; Soderhall, S.; Vettenranta, K.; Weinshilboum, R.; Wesenberg, F.; Nordic Society of Paediatric Haematology and Oncology. Thiopurine methyltransferase activity is related to the risk of relapse of childhood acute lymphoblastic leukemia: Results from the NOPHO ALL-92 study. Leukemia 2009, 23, 557-564. [CrossRef] [PubMed]

114. Silva, M.R.; de Oliveira, B.M.; Viana, M.B.; Murao, M.; Romanha, A.J. Thiopurine S-methyltransferase (TPMT) gene polymorphism in Brazilian children with acute lymphoblastic leukemia: Association with clinical and laboratory data. Ther. Drug Monit. 2008, 30, 700-704. [CrossRef] [PubMed] 
115. Stanulla, M.; Schaeffeler, E.; Flohr, T.; Cario, G.; Schrauder, A.; Zimmermann, M.; Welte, K.; Ludwig, W.D.; Bartram, C.R.; Zanger, U.M.; et al. Thiopurine methyltransferase (TPMT) genotype and early treatment response to mercaptopurine in childhood acute lymphoblastic leukemia. JAMA 2005, 293, 1485-1489. [CrossRef] [PubMed]

116. Stanulla, M.; Schaeffeler, E.; Moricke, A.; Coulthard, S.A.; Cario, G.; Schrauder, A.; Kaatsch, P.; Dordelmann, M.; Welte, K.; Zimmermann, M.; et al. Thiopurine methyltransferase genetics is not a major risk factor for secondary malignant neoplasms after treatment of childhood acute lymphoblastic leukemia on Berlin-Frankfurt-Munster protocols. Blood 2009, 114, 1314-1318. [CrossRef] [PubMed]

117. Stocco, G.; Martelossi, S.; Barabino, A.; Fontana, M.; Lionetti, P.; Decorti, G.; Malusa, N.; Bartoli, F.; Fezzi, M.; Giraldi, T.; et al. TPMT genotype and the use of thiopurines in paediatric inflammatory bowel disease. Dig. Liver Dis. 2005, 37, 940-945. [CrossRef] [PubMed]

118. Tumer, T.B.; Ulusoy, G.; Adali, O.; Sahin, G.; Gozdasoglu, S.; Arinc, E. The low frequency of defective TPMT alleles in Turkish population: A study on pediatric patients with acute lymphoblastic leukemia. Am. J. Hematol. 2007, 82, 906-910. [CrossRef] [PubMed]

119. Zhang, F.; Gao, X.; Ding, L.; Liu, H.; Wang, X.; Chen, B.; Bi, H.; Xiao, Y.; Cheng, P.; Zhao, L.; et al. Prospective Evaluation of Pharmacogenomics and Metabolite Measurements upon Azathioprine Therapy in Inflammatory Bowel Disease: An Observational Study. Medicine (Baltimore) 2016, 95, e3326.

120. Chiengthong, K.; Ittiwut, C.; Muensri, S.; Sophonphan, J.; Sosothikul, D.; Seksan, P.; Suppipat, K.; Suphapeetiporn, K.; Shotelersuk, V. NUDT15 c.415C $>$ T increases risk of 6-mercaptopurine induced myelosuppression during maintenance therapy in children with acute lymphoblastic leukemia. Haematologica 2016, 101, e24-e26. [CrossRef] [PubMed]

121. Lee, Y.J.; Hwang, E.H.; Park, J.H.; Shin, J.H.; Kang, B.; Kim, S.Y. NUDT15 variant is the most common variant associated with thiopurine-induced early leukopenia and alopecia in Korean pediatric patients with Crohn's disease. Eur. J. Gastroenterol. Hepatol. 2016, 28, 475-478. [CrossRef] [PubMed]

122. Liang, D.C.; Yang, C.P.; Liu, H.C.; Jaing, T.H.; Chen, S.H.; Hung, I.J.; Yeh, T.C.; Lin, T.H.; Lai, C.L.; Lai, C.Y.; et al. NUDT15 gene polymorphism related to mercaptopurine intolerance in Taiwan Chinese children with acute lymphoblastic leukemia. Pharmacogenom. J. 2015. [CrossRef] [PubMed]

123. Moriyama, T.; Nishii, R.; Perez-Andreu, V.; Yang, W.; Klussmann, F.A.; Zhao, X.; Lin, T.N.; Hoshitsuki, K.; Nersting, J.; Kihira, K.; et al. NUDT15 polymorphisms alter thiopurine metabolism and hematopoietic toxicity. Nat. Genet. 2016, 48, 367-373. [CrossRef] [PubMed]

124. Suzuki, H.; Fukushima, H.; Suzuki, R.; Hosaka, S.; Yamaki, Y.; Kobayashi, C.; Sakai, A.; Imagawa, K.; Iwabuchi, A.; Yoshimi, A.; et al. Genotyping NUDT15 can predict the dose reduction of 6-MP for children with acute lymphoblastic leukemia especially at a preschool age. J. Hum. Genet. 2016. [CrossRef] [PubMed]

125. Tanaka, Y.; Kato, M.; Hasegawa, D.; Urayama, K.Y.; Nakadate, H.; Kondoh, K.; Nakamura, K.; Koh, K.; Komiyama, T.; Manabe, A. Susceptibility to 6-MP toxicity conferred by a NUDT15 variant in Japanese children with acute lymphoblastic leukaemia. Br. J. Haematol. 2015, 171, 109-115. [CrossRef] [PubMed]

126. Yang, J.J.; Landier, W.; Yang, W.; Liu, C.; Hageman, L.; Cheng, C.; Pei, D.; Chen, Y.; Crews, K.R.; Kornegay, N.; et al. Inherited NUDT15 variant is a genetic determinant of mercaptopurine intolerance in children with acute lymphoblastic leukemia. J. Clin. Oncol. 2015, 33, 1235-1242. [CrossRef] [PubMed]

127. Ailing, Z.; Jing, Y.; Jingli, L.; Yun, X.; Xiaojian, Z. Further evidence that a variant of the gene NUDT15 may be an important predictor of azathioprine-induced toxicity in Chinese subjects: A case report. J. Clin. Pharm. Ther. 2016, 41, 572-574. [CrossRef] [PubMed]

128. Asada, A.; Nishida, A.; Shioya, M.; Imaeda, H.; Inatomi, O.; Bamba, S.; Kito, K.; Sugimoto, M.; Andoh, A. NUDT15 R139C-related thiopurine leukocytopenia is mediated by 6-thioguanine nucleotide-independent mechanism in Japanese patients with inflammatory bowel disease. J. Gastroenterol. 2016, 51, 22-29. [CrossRef] [PubMed]

129. Kakuta, Y.; Naito, T.; Onodera, M.; Kuroha, M.; Kimura, T.; Shiga, H.; Endo, K.; Negoro, K.; Kinouchi, Y.; Shimosegawa, T. NUDT15 R139C causes thiopurine-induced early severe hair loss and leukopenia in Japanese patients with IBD. Pharmacogenom. J. 2015. [CrossRef] [PubMed]

130. Shah, S.A.; Paradkar, M.; Desai, D.; Ashavaid, T.F. Nudt15 C415t Variant as a Predictor For Thiopurine Induced Toxicity in Indian Patients. J. Gastroenterol. Hepatol. 2016. [CrossRef] [PubMed]

131. Wong, F.C.; Leung, A.W.; Kwok, J.S.; Chan, M.H.; Li, C.K.; Yuen, Y.P. NUDT15 variant and thiopurine-induced leukopenia in Hong Kong. Hong Kong Med. J. 2016, 22, 185-187. [CrossRef] [PubMed] 
132. Yang, S.K.; Hong, M.; Baek, J.; Choi, H.; Zhao, W.; Jung, Y.; Haritunians, T.; Ye, B.D.; Kim, K.J.; Park, S.H.; et al. A common missense variant in NUDT15 confers susceptibility to thiopurine-induced leukopenia. Nat. Genet. 2014, 46, 1017-1020. [CrossRef] [PubMed]

133. Caronia, D.; Patino-Garcia, A.; Milne, R.L.; Zalacain-Diez, M.; Pita, G.; Alonso, M.R.; Moreno, L.T.; Sierrasesumaga-Ariznabarreta, L.; Benitez, J.; Gonzalez-Neira, A. Common variations in ERCC2 are associated with response to cisplatin chemotherapy and clinical outcome in osteosarcoma patients. Pharmacogenom. J. 2009, 9, 347-353. [CrossRef] [PubMed]

134. Sakano, S.; Hinoda, Y.; Sasaki, M.; Wada, T.; Matsumoto, H.; Eguchi, S.; Shinohara, A.; Kawai, Y.; Hara, T.; Nagao, K.; et al. Nucleotide excision repair gene polymorphisms may predict acute toxicity in patients treated with chemoradiotherapy for bladder cancer. Pharmacogenomics 2010, 11, 1377-1387. [CrossRef] [PubMed]

135. Bradbury, P.A.; Kulke, M.H.; Heist, R.S.; Zhou, W.; Ma, C.; Xu, W.; Marshall, A.L.; Zhai, R.; Hooshmand, S.M.; Asomaning, K.; et al. Cisplatin pharmacogenetics, DNA repair polymorphisms, and esophageal cancer outcomes. Pharmacogenet. Genom. 2009, 19, 613-625. [CrossRef] [PubMed]

136. Giovannetti, E.; Pacetti, P.; Reni, M.; Leon, L.G.; Mambrini, A.; Vasile, E.; Ghidini, M.; Funel, N.; Lucchesi, M.; Cereda, S.; et al. Association between DNA-repair polymorphisms and survival in pancreatic cancer patients treated with combination chemotherapy. Pharmacogenomics 2011, 12, 1641-1652. [CrossRef] [PubMed]

137. Huang, M.Y.; Huang, M.L.; Chen, M.J.; Lu, C.Y.; Chen, C.F.; Tsai, P.C.; Chuang, S.C.; Hou, M.F.; Lin, S.R.; Wang, J.Y. Multiple genetic polymorphisms in the prediction of clinical outcome of metastatic colorectal cancer patients treated with first-line FOLFOX-4 chemotherapy. Pharmacogenet. Genom. 2011, 21, 18-25. [CrossRef] [PubMed]

138. Kalikaki, A.; Kanaki, M.; Vassalou, H.; Souglakos, J.; Voutsina, A.; Georgoulias, V.; Mavroudis, D. DNA repair gene polymorphisms predict favorable clinical outcome in advanced non-small-cell lung cancer. Clin. Lung Cancer 2009, 10, 118-123. [CrossRef] [PubMed]

139. Khrunin, A.; Ivanova, F.; Moisseev, A.; Khokhrin, D.; Sleptsova, Y.; Gorbunova, V.; Limborska, S. Pharmacogenomics of cisplatin-based chemotherapy in ovarian cancer patients of different ethnic origins. Pharmacogenomics 2012, 13, 171-178. [CrossRef] [PubMed]

140. Khrunin, A.V.; Moisseev, A.; Gorbunova, V.; Limborska, S. Genetic polymorphisms and the efficacy and toxicity of cisplatin-based chemotherapy in ovarian cancer patients. Pharmacogenom. J. 2010, 10, 54-61. [CrossRef] [PubMed]

141. Stoehlmacher, J.; Park, D.J.; Zhang, W.; Yang, D.; Groshen, S.; Zahedy, S.; Lenz, H.J. A multivariate analysis of genomic polymorphisms: Prediction of clinical outcome to 5-FU/oxaliplatin combination chemotherapy in refractory colorectal cancer. Br. J. Cancer 2004, 91, 344-354. [CrossRef] [PubMed]

142. Sullivan, I.; Salazar, J.; Majem, M.; Pallares, C.; Del Rio, E.; Paez, D.; Baiget, M.; Barnadas, A. Pharmacogenetics of the DNA repair pathways in advanced non-small cell lung cancer patients treated with platinum-based chemotherapy. Cancer Lett. 2014, 353, 160-166. [CrossRef] [PubMed]

143. Tzvetkov, M.V.; Behrens, G.; O'Brien, V.P.; Hohloch, K.; Brockmoller, J.; Benohr, P. Pharmacogenetic analyses of cisplatin-induced nephrotoxicity indicate a renoprotective effect of ERCC1 polymorphisms. Pharmacogenomics 2011, 12, 1417-1427. [CrossRef] [PubMed]

144. Yan, L.; Shu-Ying, Y.; Shan, K.; Yip, B.H.; Rong-Miao, Z.; Na, W.; Hai-Yan, S. Association between polymorphisms of ERCC1 and survival in epithelial ovarian cancer patients with chemotherapy. Pharmacogenomics 2012, 13, 419-427. [CrossRef] [PubMed]

145. Zucali, P.A.; Giovannetti, E.; Destro, A.; Mencoboni, M.; Ceresoli, G.L.; Gianoncelli, L.; Lorenzi, E.; De Vincenzo, F.; Simonelli, M.; Perrino, M.; et al. Thymidylate synthase and excision repair cross-complementing group-1 as predictors of responsiveness in mesothelioma patients treated with pemetrexed/carboplatin. Clin. Cancer Res. 2011, 17, 2581-2590. [CrossRef] [PubMed]

146. Perez-Ramirez, C.; Canadas-Garre, M.; Alnatsha, A.; Villar, E.; Delgado, J.R.; Faus-Dader, M.J.; Calleja-Hernandez, M.A. Pharmacogenetic predictors of toxicity to platinum based chemotherapy in non-small cell lung cancer patients. Pharmacol. Res. 2016, 111, 877-884. [CrossRef] [PubMed]

147. Tibaldi, C.; Giovannetti, E.; Vasile, E.; Mey, V.; Laan, A.C.; Nannizzi, S.; di Marsico, R.; Antonuzzo, A.; Orlandini, C.; Ricciardi, S.; et al. Correlation of CDA, ERCC1, and XPD polymorphisms with response and survival in gemcitabine/cisplatin-treated advanced non-small cell lung cancer patients. Clin. Cancer Res. 2008, 14, 1797-1803. [CrossRef] [PubMed] 
148. Abbas, M.; Kushwaha, V.S.; Srivastava, K.; Banerjee, M. Glutathione S-Transferase Gene Polymorphisms and Treatment Outcome in Cervical Cancer Patients under Concomitant Chemoradiation. PLoS ONE 2015, 10, e0142501. [CrossRef] [PubMed]

149. Kap, E.J.; Richter, S.; Rudolph, A.; Jansen, L.; Ulrich, A.; Hoffmeister, M.; Ulrich, C.M.; Brenner, H.; Chang-Claude, J. Genetic variants in the glutathione $S$-transferase genes and survival in colorectal cancer patients after chemotherapy and differences according to treatment with oxaliplatin. Pharmacogenet. Genom. 2014, 24, 340-347. [CrossRef] [PubMed]

150. Pereira, D.; Assis, J.; Gomes, M.; Nogueira, A.; Medeiros, R. Improvement of a predictive model in ovarian cancer patients submitted to platinum-based chemotherapy: Implications of a GST activity profile. Eur. J. Clin. Pharmacol. 2016, 72, 545-553. [CrossRef] [PubMed]

151. Henriquez-Hernandez, L.A.; Murias-Rosales, A.; Gonzalez-Hernandez, A.; de Leon, A.C.; Diaz-Chico, N.; Fernandez-Perez, L. Distribution of TYMS, MTHFR, p53 and MDR1 gene polymorphisms in patients with breast cancer treated with neoadjuvant chemotherapy. Cancer Epidemiol. 2010, 34, 634-638. [CrossRef] [PubMed]

152. Huang, Z.H.; Hua, D.; Li, L.H.; Zhu, J.D. Prognostic role of p53 codon 72 polymorphism in gastric cancer patients treated with fluorouracil-based adjuvant chemotherapy. J. Cancer Res. Clin. Oncol. 2008, 134, 1129-1134. [CrossRef] [PubMed]

153. Kim, J.G.; Sohn, S.K.; Chae, Y.S.; Song, H.S.; Kwon, K.Y.; Do, Y.R.; Kim, M.K.; Lee, K.H.; Hyun, M.S.; Lee, W.S.; et al. TP53 codon 72 polymorphism associated with prognosis in patients with advanced gastric cancer treated with paclitaxel and cisplatin. Cancer Chemother. Pharmacol. 2009, 64, 355-360. [CrossRef] [PubMed]

154. Chung, H.H.; Kim, M.K.; Kim, J.W.; Park, N.H.; Song, Y.S.; Kang, S.B.; Lee, H.P. XRCC1 R399Q polymorphism is associated with response to platinum-based neoadjuvant chemotherapy in bulky cervical cancer. Gynecol. Oncol. 2006, 103, 1031-1037. [CrossRef] [PubMed]

155. Jin, H.; Xie, X.; Wang, H.; Hu, J.; Liu, F.; Liu, Z.; Zhou, J.; Zhang, Y.; Xi, X.; Hu, B.; et al. ERCC1 Cys8092Ala and XRCC1 Arg399Gln polymorphisms predict progression-free survival after curative radiotherapy for nasopharyngeal carcinoma. PLoS ONE 2014, 9, e101256. [CrossRef] [PubMed]

156. Yin, J.Y.; Huang, Q.; Zhao, Y.C.; Zhou, H.H.; Liu, Z.Q. Meta-analysis on pharmacogenetics of platinum-based chemotherapy in non small cell lung cancer (NSCLC) patients. PLoS ONE 2012, 7, e38150. [CrossRef] [PubMed]

157. Zhang, L.; Ma, W.; Li, Y.; Wu, J.; Shi, G.Y. Pharmacogenetics of DNA repair gene polymorphisms in non-small-cell lung carcinoma patients on platinum-based chemotherapy. Genet. Mol. Res. 2014, 13, 228-236. [CrossRef] [PubMed]

158. Goto, K.; Ichinose, Y.; Ohe, Y.; Yamamoto, N.; Negoro, S.; Nishio, K.; Itoh, Y.; Jiang, H.; Duffield, E.; McCormack, R.; et al. Epidermal growth factor receptor mutation status in circulating free DNA in serum: From IPASS, a phase III study of gefitinib or carboplatin/paclitaxel in non-small cell lung cancer. J. Thorac. Oncol. 2012, 7, 115-121. [CrossRef] [PubMed]

159. Han, J.Y.; Park, K.; Kim, S.W.; Lee, D.H.; Kim, H.Y.; Kim, H.T.; Ahn, M.J.; Yun, T.; Ahn, J.S.; Suh, C.; et al. First-SIGNAL: First-line single-agent iressa versus gemcitabine and cisplatin trial in never-smokers with adenocarcinoma of the lung. J. Clin. Oncol. 2012, 30, 1122-1128. [CrossRef] [PubMed]

160. Maemondo, M.; Inoue, A.; Kobayashi, K.; Sugawara, S.; Oizumi, S.; Isobe, H.; Gemma, A.; Harada, M.; Yoshizawa, H.; Kinoshita, I.; et al. Gefitinib or chemotherapy for non-small-cell lung cancer with mutated EGFR. N. Engl. J. Med. 2010, 362, 2380-2388. [CrossRef] [PubMed]

161. Mitsudomi, T.; Morita, S.; Yatabe, Y.; Negoro, S.; Okamoto, I.; Tsurutani, J.; Seto, T.; Satouchi, M.; Tada, H.; Hirashima, T.; et al. Gefitinib versus cisplatin plus docetaxel in patients with non-small-cell lung cancer harbouring mutations of the epidermal growth factor receptor (WJTOG3405): An open label, randomised phase 3 trial. Lancet Oncol. 2010, 11, 121-128. [CrossRef]

162. Mok, T.S.; Wu, Y.L.; Thongprasert, S.; Yang, C.H.; Chu, D.T.; Saijo, N.; Sunpaweravong, P.; Han, B.; Margono, B.; Ichinose, Y.; et al. Gefitinib or carboplatin-paclitaxel in pulmonary adenocarcinoma. N. Engl. J. Med. 2009, 361, 947-957. [CrossRef] [PubMed]

163. Oizumi, S.; Kobayashi, K.; Inoue, A.; Maemondo, M.; Sugawara, S.; Yoshizawa, H.; Isobe, H.; Harada, M.; Kinoshita, I.; Okinaga, S.; et al. Quality of life with gefitinib in patients with EGFR-mutated non-small cell lung cancer: Quality of life analysis of North East Japan Study Group 002 Trial. Oncologist 2012, 17, 863-870. [CrossRef] [PubMed] 
164. Rosell, R.; Carcereny, E.; Gervais, R.; Vergnenegre, A.; Massuti, B.; Felip, E.; Palmero, R.; Garcia-Gomez, R.; Pallares, C.; Sanchez, J.M.; et al. Erlotinib versus standard chemotherapy as first-line treatment for European patients with advanced EGFR mutation-positive non-small-cell lung cancer (EURTAC): A multicentre, open-label, randomised phase 3 trial. Lancet Oncol. 2012, 13, 239-246. [CrossRef]

165. Zhou, C.; Wu, Y.L.; Chen, G.; Feng, J.; Liu, X.Q.; Wang, C.; Zhang, S.; Wang, J.; Zhou, S.; Ren, S.; et al. Erlotinib versus chemotherapy as first-line treatment for patients with advanced EGFR mutation-positive non-small-cell lung cancer (OPTIMAL, CTONG-0802): A multicentre, open-label, randomised, phase 3 study. Lancet Oncol. 2011, 12, 735-742. [CrossRef]

166. Cui, L.H.; Yu, Z.; Zhang, T.T.; Shin, M.H.; Kim, H.N.; Choi, J.S. Influence of polymorphisms in MTHFR 677 $\mathrm{C} \rightarrow \mathrm{T}, \mathrm{TYMS} 3 \mathrm{R} \rightarrow 2 \mathrm{R}$ and MTR $2756 \mathrm{~A} \rightarrow \mathrm{G}$ on NSCLC risk and response to platinum-based chemotherapy in advanced NSCLC. Pharmacogenomics 2011, 12, 797-808. [CrossRef] [PubMed]

167. Smit, E.F.; Burgers, S.A.; Biesma, B.; Smit, H.J.; Eppinga, P.; Dingemans, A.M.; Joerger, M.; Schellens, J.H.; Vincent, A.; van Zandwijk, N.; et al. Randomized phase II and pharmacogenetic study of pemetrexed compared with pemetrexed plus carboplatin in pretreated patients with advanced non-small-cell lung cancer. J. Clin. Oncol. 2009, 27, 2038-2045. [CrossRef] [PubMed]

168. Gregers, J.; Green, H.; Christensen, I.J.; Dalhoff, K.; Schroeder, H.; Carlsen, N.; Rosthoej, S.; Lausen, B.; Schmiegelow, K.; Peterson, C. Polymorphisms in the ABCB1 gene and effect on outcome and toxicity in childhood acute lymphoblastic leukemia. Pharmacogenom. J. 2015, 15, 372-379. [CrossRef] [PubMed]

169. Suthandiram, S.; Gan, G.G.; Zain, S.M.; Bee, P.C.; Lian, L.H.; Chang, K.M.; Ong, T.C.; Mohamed, Z. Effect of polymorphisms within methotrexate pathway genes on methotrexate toxicity and plasma levels in adults with hematological malignancies. Pharmacogenomics 2014, 15, 1479-1494. [CrossRef] [PubMed]

170. Zgheib, N.K.; Akra-Ismail, M.; Aridi, C.; Mahfouz, R.; Abboud, M.R.; Solh, H.; Muwakkit, S.A. Genetic polymorphisms in candidate genes predict increased toxicity with methotrexate therapy in Lebanese children with acute lymphoblastic leukemia. Pharmacogenet. Genom. 2014, 24, 387-396. [CrossRef] [PubMed]

171. Iannaccone, C.K.; Lee, Y.C.; Cui, J.; Frits, M.L.; Glass, R.J.; Plenge, R.M.; Solomon, D.H.; Weinblatt, M.E.; Shadick, N.A. Using genetic and clinical data to understand response to disease-modifying anti-rheumatic drug therapy: Data from the Brigham and Women's Hospital Rheumatoid Arthritis Sequential Study. Rheumatology 2011, 50, 40-46. [CrossRef] [PubMed]

172. Lee, Y.C.; Cui, J.; Costenbader, K.H.; Shadick, N.A.; Weinblatt, M.E.; Karlson, E.W. Investigation of candidate polymorphisms and disease activity in rheumatoid arthritis patients on methotrexate. Rheumatology 2009, 48, 613-617. [CrossRef] [PubMed]

173. Aplenc, R.; Thompson, J.; Han, P.; La, M.; Zhao, H.; Lange, B.; Rebbeck, T. Methylenetetrahydrofolate reductase polymorphisms and therapy response in pediatric acute lymphoblastic leukemia. Cancer Res. 2005, 65, 2482-2487. [CrossRef] [PubMed]

174. Araoz, H.V.; D'Aloi, K.; Foncuberta, M.E.; Sanchez La Rosa, C.G.; Alonso, C.N.; Chertkoff, L.; Felice, M. Pharmacogenetic studies in children with acute lymphoblastic leukemia in Argentina. Leuk. Lymphoma 2015, 56, 1370-1378. [CrossRef] [PubMed]

175. Costea, I.; Moghrabi, A.; Laverdiere, C.; Graziani, A.; Krajinovic, M. Folate cycle gene variants and chemotherapy toxicity in pediatric patients with acute lymphoblastic leukemia. Haematologica 2006, 91, 1113-1116. [PubMed]

176. D'Angelo, V.; Ramaglia, M.; Iannotta, A.; Francese, M.; Pota, E.; Affinita, M.C.; Pecoraro, G.; Indolfi, C.; di Martino, M.; di Pinto, D.; et al. Influence of methylenetetrahydrofolate reductase gene polymorphisms on the outcome of pediatric patients with non-Hodgkin lymphoma treated with high-dose methotrexate. Leuk. Lymphoma 2013, 54, 2639-2644. [CrossRef] [PubMed]

177. Dorababu, P.; Naushad, S.M.; Linga, V.G.; Gundeti, S.; Nagesh, N.; Kutala, V.K.; Reddanna, P.; Digumarti, R. Genetic variants of thiopurine and folate metabolic pathways determine 6-MP-mediated hematological toxicity in childhood ALL. Pharmacogenomics 2012, 13, 1001-1008. [CrossRef] [PubMed]

178. El-Khodary, N.M.; El-Haggar, S.M.; Eid, M.A.; Ebeid, E.N. Study of the pharmacokinetic and pharmacogenetic contribution to the toxicity of high-dose methotrexate in children with acute lymphoblastic leukemia. Med. Oncol. 2012, 29, 2053-2062. [CrossRef] [PubMed] 
179. Hagleitner, M.M.; Coenen, M.J.; Aplenc, R.; Patino-Garcia, A.; Chiusolo, P.; Gemmati, D.; de Mattei, M.; Ongaro, A.; Krajinovic, M.; Hoogerbrugge, P.M.; et al. The role of the MTHFR 677C >T polymorphism in methotrexate-induced liver toxicity: A meta-analysis in patients with cancer. Pharmacogenom. J. 2014, 14, 115-119. [CrossRef] [PubMed]

180. He, H.R.; Chen, S.Y.; You, H.S.; Hu, S.S.; Sun, J.Y.; Dong, Y.L.; Lu, J. Association between methylenetetrahydrofolate reductase polymorphisms and the relapse of acute lymphoblastic leukemia: A meta-analysis. Pharmacogenom. J. 2014, 14, 432-438. [CrossRef] [PubMed]

181. Imanishi, H.; Okamura, N.; Yagi, M.; Noro, Y.; Moriya, Y.; Nakamura, T.; Hayakawa, A.; Takeshima, Y.; Sakaeda, T.; Matsuo, M.; et al. Genetic polymorphisms associated with adverse events and elimination of methotrexate in childhood acute lymphoblastic leukemia and malignant lymphoma. J. Hum. Genet. 2007, 52, 166-171. [CrossRef] [PubMed]

182. Jazbec, J.; Kitanovski, L.; Aplenc, R.; Debeljak, M.; Dolzan, V. No evidence of association of methylenetetrahydrofolate reductase polymorphism with occurrence of second neoplasms after treatment of childhood leukemia. Leuk. Lymphoma 2005, 46, 893-897. [CrossRef] [PubMed]

183. Kishi, S.; Griener, J.; Cheng, C.; Das, S.; Cook, E.H.; Pei, D.; Hudson, M.; Rubnitz, J.; Sandlund, J.T.; Pui, C.H.; et al. Homocysteine, pharmacogenetics, and neurotoxicity in children with leukemia. J. Clin. Oncol. 2003, 21, 3084-3091. [CrossRef] [PubMed]

184. Krajinovic, M.; Lemieux-Blanchard, E.; Chiasson, S.; Primeau, M.; Costea, I.; Moghrabi, A. Role of polymorphisms in MTHFR and MTHFD1 genes in the outcome of childhood acute lymphoblastic leukemia. Pharmacogenom. J. 2004, 4, 66-72. [CrossRef] [PubMed]

185. Krajinovic, M.; Robaey, P.; Chiasson, S.; Lemieux-Blanchard, E.; Rouillard, M.; Primeau, M.; Bournissen, F.G.; Moghrabi, A. Polymorphisms of genes controlling homocysteine levels and IQ score following the treatment for childhood ALL. Pharmacogenomics 2005, 6, 293-302. [CrossRef] [PubMed]

186. Lopez-Lopez, E.; Martin-Guerrero, I.; Ballesteros, J.; Garcia-Orad, A. A systematic review and meta-analysis of MTHFR polymorphisms in methotrexate toxicity prediction in pediatric acute lymphoblastic leukemia. Pharmacogenom. J. 2013, 13, 498-506. [CrossRef] [PubMed]

187. Pakakasama, S.; Kanchanakamhaeng, K.; Kajanachumpol, S.; Udomsubpayakul, U.; Sirachainan, N.; Thithapandha, A.; Hongeng, S. Genetic polymorphisms of folate metabolic enzymes and toxicities of high dose methotrexate in children with acute lymphoblastic leukemia. Ann. Hematol. 2007, 86, 609-611. [CrossRef] [PubMed]

188. Patino-Garcia, A.; Zalacain, M.; Marrodan, L.; San-Julian, M.; Sierrasesumaga, L. Methotrexate in pediatric osteosarcoma: Response and toxicity in relation to genetic polymorphisms and dihydrofolate reductase and reduced folate carrier 1 expression. J. Pediatri. 2009, 154, 688-693. [CrossRef] [PubMed]

189. Roy Moulik, N.; Kumar, A.; Agrawal, S.; Awasthi, S.; Mahdi, A.A.; Kumar, A. Role of folate status and methylenetetrahydrofolate reductase genotype on the toxicity and outcome of induction chemotherapy in children with acute lymphoblastic leukemia. Leuk. Lymphoma 2015, 56, 1379-1384. [CrossRef] [PubMed]

190. Salazar, J.; Altes, A.; del Rio, E.; Estella, J.; Rives, S.; Tasso, M.; Navajas, A.; Molina, J.; Villa, M.; Vivanco, J.L.; et al. Methotrexate consolidation treatment according to pharmacogenetics of MTHFR ameliorates event-free survival in childhood acute lymphoblastic leukaemia. Pharmacogenom. J. 2012, 12, 379-385. [CrossRef] [PubMed]

191. Seidemann, K.; Book, M.; Zimmermann, M.; Meyer, U.; Welte, K.; Stanulla, M.; Reiter, A. MTHFR 677 (C $\rightarrow$ T) polymorphism is not relevant for prognosis or therapy-associated toxicity in pediatric NHL: Results from 484 patients of multicenter trial NHL-BFM 95. Ann. Hematol. 2006, 85, 291-300. [CrossRef] [PubMed]

192. Shimasaki, N.; Mori, T.; Samejima, H.; Sato, R.; Shimada, H.; Yahagi, N.; Torii, C.; Yoshihara, H.; Tanigawara, Y.; Takahashi, T.; et al. Effects of methylenetetrahydrofolate reductase and reduced folate carrier 1 polymorphisms on high-dose methotrexate-induced toxicities in children with acute lymphoblastic leukemia or lymphoma. J. Pediatr. Hematol. Oncol. 2006, 28, 64-68. [CrossRef] [PubMed]

193. Shimasaki, N.; Mori, T.; Torii, C.; Sato, R.; Shimada, H.; Tanigawara, Y.; Kosaki, K.; Takahashi, T. Influence of MTHFR and RFC1 polymorphisms on toxicities during maintenance chemotherapy for childhood acute lymphoblastic leukemia or lymphoma. J. Pediatr. Hematol. Oncol. 2008, 30, 347-352. [CrossRef] [PubMed]

194. Spyridopoulou, K.P.; Dimou, N.L.; Hamodrakas, S.J.; Bagos, P.G. Methylene tetrahydrofolate reductase gene polymorphisms and their association with methotrexate toxicity: A meta-analysis. Pharmacogenet. Genom. 2012, 22, 117-133. [CrossRef] [PubMed] 
195. Tsujimoto, S.I.; Yanagimachi, M.; Tanoshima, R.; Urayama, K.Y.; Tanaka, F.; Aida, N.; Goto, H.; Ito, S. Influence of ADORA2A gene polymorphism on leukoencephalopathy risk in MTX-treated pediatric patients affected by hematological malignancies. Pediatr. Blood Cancer 2016. [CrossRef] [PubMed]

196. Yanagimachi, M.; Goto, H.; Kaneko, T.; Naruto, T.; Sasaki, K.; Takeuchi, M.; Tanoshima, R.; Kato, H.; Yokosuka, T.; Kajiwara, R.; et al. Influence of pre-hydration and pharmacogenetics on plasma methotrexate concentration and renal dysfunction following high-dose methotrexate therapy. Int. J. Hematol. 2013, 98, 702-707. [CrossRef] [PubMed]

197. Brooks, J.D.; Teraoka, S.N.; Bernstein, L.; Mellemkjaer, L.; Malone, K.E.; Lynch, C.F.; Haile, R.W.; Concannon, P.; Reiner, A.S.; Duggan, D.J.; et al. Common variants in genes coding for chemotherapy metabolizing enzymes, transporters, and targets: A case-control study of contralateral breast cancer risk in the WECARE Study. Cancer Causes Control. 2013, 24, 1605-1614. [CrossRef] [PubMed]

198. Chaturvedi, P.; Tulsyan, S.; Agarwal, G.; Lal, P.; Agrawal, S.; Mittal, R.D.; Mittal, B. Relationship of MTHFR and NQO1 Pharmacogenetics and Chemotherapy Clinical Outcomes in Breast Cancer Patients. Biochem. Genet. 2015, 53, 211-222. [CrossRef] [PubMed]

199. Chiusolo, P.; Reddiconto, G.; Casorelli, I.; Laurenti, L.; Sora, F.; Mele, L.; Annino, L.; Leone, G.; Sica, S. Preponderance of methylenetetrahydrofolate reductase C677T homozygosity among leukemia patients intolerant to methotrexate. Ann. Oncol. 2002, 13, 1915-1918. [CrossRef] [PubMed]

200. Chiusolo, P.; Reddiconto, G.; Farina, G.; Mannocci, A.; Fiorini, A.; Palladino, M.; La Torre, G.; Fianchi, L.; Sora, F.; Laurenti, L.; et al. MTHFR polymorphisms' influence on outcome and toxicity in acute lymphoblastic leukemia patients. Leuk. Res. 2007, 31, 1669-1674. [CrossRef] [PubMed]

201. Gemmati, D.; Ongaro, A.; Tognazzo, S.; Catozzi, L.; Federici, F.; Mauro, E.; della Porta, M.; Campioni, D.; Bardi, A.; Gilli, G.; et al. Methylenetetrahydrofolate reductase C677T and A1298C gene variants in adult non-Hodgkin's lymphoma patients: Association with toxicity and survival. Haematologica 2007, 92, 478-485. [CrossRef] [PubMed]

202. Jabeen, S.; Holmboe, L.; Alnaes, G.I.; Andersen, A.M.; Hall, K.S.; Kristensen, V.N. Impact of genetic variants of RFC1, DHFR and MTHFR in osteosarcoma patients treated with high-dose methotrexate. Pharmacogenom. J. 2015, 15, 385-390. [CrossRef] [PubMed]

203. Ongaro, A.; De Mattei, M.; Della Porta, M.G.; Rigolin, G.; Ambrosio, C.; Di Raimondo, F.; Pellati, A.; Masieri, F.F.; Caruso, A.; Catozzi, L.; et al. Gene polymorphisms in folate metabolizing enzymes in adult acute lymphoblastic leukemia: Effects on methotrexate-related toxicity and survival. Haematologica 2009, 94, 1391-1398. [CrossRef] [PubMed]

204. Robien, K.; Schubert, M.M.; Bruemmer, B.; Lloid, M.E.; Potter, J.D.; Ulrich, C.M. Predictors of oral mucositis in patients receiving hematopoietic cell transplants for chronic myelogenous leukemia. J. Clin. Oncol. 2004, 22, 1268-1275. [CrossRef] [PubMed]

205. Robien, K.; Schubert, M.M.; Chay, T.; Bigler, J.; Storb, R.; Yasui, Y.; Potter, J.D.; Ulrich, C.M. Methylenetetrahydrofolate reductase and thymidylate synthase genotypes modify oral mucositis severity following hematopoietic stem cell transplantation. Bone Marrow Transplant. 2006, 37, 799-800. [CrossRef] [PubMed]

206. Ulrich, C.M.; Yasui, Y.; Storb, R.; Schubert, M.M.; Wagner, J.L.; Bigler, J.; Ariail, K.S.; Keener, C.L.; Li, S.; Liu, H.; et al. Pharmacogenetics of methotrexate: Toxicity among marrow transplantation patients varies with the methylenetetrahydrofolate reductase C677T polymorphism. Blood 2001, 98, 231-234. [CrossRef] [PubMed]

207. De Jonge, R.; Hooijberg, J.H.; van Zelst, B.D.; Jansen, G.; van Zantwijk, C.H.; Kaspers, G.J.; Peters, G.J.; Ravindranath, Y.; Pieters, R.; Lindemans, J. Effect of polymorphisms in folate-related genes on in vitro methotrexate sensitivity in pediatric acute lymphoblastic leukemia. Blood 2005, 106, 717-720. [CrossRef] [PubMed]

208. Huang, L.; Tissing, W.J.; de Jonge, R.; van Zelst, B.D.; Pieters, R. Polymorphisms in folate-related genes: Association with side effects of high-dose methotrexate in childhood acute lymphoblastic leukemia. Leukemia 2008, 22, 1798-1800. [CrossRef] [PubMed]

209. Goricar, K.; Kovac, V.; Jazbec, J.; Zakotnik, B.; Lamovec, J.; Dolzan, V. Influence of the folate pathway and transporter polymorphisms on methotrexate treatment outcome in osteosarcoma. Pharmacogenet. Genom. 2014, 24, 514-521. [CrossRef] [PubMed] 
210. Ramsey, L.B.; Panetta, J.C.; Smith, C.; Yang, W.; Fan, Y.; Winick, N.J.; Martin, P.L.; Cheng, C.; Devidas, M.; Pui, C.H.; et al. Genome-wide study of methotrexate clearance replicates SLCO1B1. Blood 2013, 121, 898-904. [CrossRef] [PubMed]

211. Stocco, G.; Yang, W.; Crews, K.R.; Thierfelder, W.E.; Decorti, G.; Londero, M.; Franca, R.; Rabusin, M.; Valsecchi, M.G.; Pei, D.; et al. PACSIN2 polymorphism influences TPMT activity and mercaptopurine-related gastrointestinal toxicity. Hum. Mol. Genet. 2012, 21, 4793-4804. [CrossRef] [PubMed]

212. Trevino, L.R.; Shimasaki, N.; Yang, W.; Panetta, J.C.; Cheng, C.; Pei, D.; Chan, D.; Sparreboom, A.; Giacomini, K.M.; Pui, C.H.; et al. Germline genetic variation in an organic anion transporter polypeptide associated with methotrexate pharmacokinetics and clinical effects. J. Clin. Oncol. 2009, 27, 5972-5978. [CrossRef] [PubMed]

213. Oliveira, A.L.; Rodrigues, F.F.; Santos, R.E.; Aoki, T.; Rocha, M.N.; Longui, C.A.; Melo, M.B. GSTT1, GSTM1, and GSTP1 polymorphisms and chemotherapy response in locally advanced breast cancer. Genet. Mol. Res. 2010, 9, 1045-1053. [CrossRef] [PubMed]

214. Zhang, B.L.; Sun, T.; Zhang, B.N.; Zheng, S.; Lu, N.; Xu, B.H.; Wang, X.; Chen, G.J.; Yu, D.K.; Lin, D.X. Polymorphisms of GSTP1 is associated with differences of chemotherapy response and toxicity in breast cancer. Chin. Med. J. 2011, 124, 199-204. [PubMed]

215. Glynn, S.A.; Boersma, B.J.; Howe, T.M.; Edvardsen, H.; Geisler, S.B.; Goodman, J.E.; Ridnour, L.A.; Lonning, P.E.; Borresen-Dale, A.L.; Naume, B.; et al. A mitochondrial target sequence polymorphism in manganese superoxide dismutase predicts inferior survival in breast cancer patients treated with cyclophosphamide. Clin. Cancer Res. 2009, 15, 4165-4173. [CrossRef] [PubMed]

216. Han, J.Y.; Shin, E.S.; Lee, Y.S.; Ghang, H.Y.; Kim, S.Y.; Hwang, J.A.; Kim, J.Y.; Lee, J.S. A genome-wide association study for irinotecan-related severe toxicities in patients with advanced non-small-cell lung cancer. Pharmacogenom. J. 2013, 13, 417-422. [CrossRef] [PubMed]

217. Ando, Y.; Saka, H.; Ando, M.; Sawa, T.; Muro, K.; Ueoka, H.; Yokoyama, A.; Saitoh, S.; Shimokata, K.; Hasegawa, Y. Polymorphisms of UDP-glucuronosyltransferase gene and irinotecan toxicity: A pharmacogenetic analysis. Cancer Res. 2000, 60, 6921-6926. [PubMed]

218. Chen, Y.J.; Hu, F.; Li, C.Y.; Fang, J.M.; Chu, L.; Zhang, X.; Xu, Q. The association of UGT1A1*6 and UGT1A1*28 with irinotecan-induced neutropenia in Asians: A Meta-analysis. Biomarkers 2014, 19, 56-62. [CrossRef] [PubMed]

219. Cheng, L.; Li, M.; Hu, J.; Ren, W.; Xie, L.; Sun, Z.P.; Liu, B.R.; Xu, G.X.; Dong, X.L.; Qian, X.P. UGT1A1*6 polymorphisms are correlated with irinotecan-induced toxicity: A system review and meta-analysis in Asians. Cancer Chemother. Pharmacol. 2014, 73, 551-660. [CrossRef] [PubMed]

220. Cote, J.F.; Kirzin, S.; Kramar, A.; Mosnier, J.F.; Diebold, M.D.; Soubeyran, I.; Thirouard, A.S.; Selves, J.; Laurent-Puig, P.; Ychou, M. UGT1A1 polymorphism can predict hematologic toxicity in patients treated with irinotecan. Clin. Cancer Res. 2007, 13, 3269-3275. [CrossRef] [PubMed]

221. De Jong, F.A.; Kehrer, D.F.; Mathijssen, R.H.; Creemers, G.J.; de Bruijn, P.; van Schaik, R.H.; Planting, A.S.; van der Gaast, A.; Eskens, F.A.; Janssen, J.T.; et al. Prophylaxis of irinotecan-induced diarrhea with neomycin and potential role for UGT1A1*28 genotype screening: A double-blind, randomized, placebo-controlled study. Oncologist 2006, 11, 944-954. [CrossRef] [PubMed]

222. De Jong, F.A.; Scott-Horton, T.J.; Kroetz, D.L.; McLeod, H.L.; Friberg, L.E.; Mathijssen, R.H.; Verweij, J.; Marsh, S.; Sparreboom, A. Irinotecan-induced diarrhea: Functional significance of the polymorphic ABCC2 transporter protein. Clin. Pharmacol. Ther. 2007, 81, 42-49. [CrossRef] [PubMed]

223. Dias, M.M.; McKinnon, R.A.; Sorich, M.J. Impact of the UGT1A1*28 allele on response to irinotecan: A systematic review and meta-analysis. Pharmacogenomics 2012, 13, 889-899. [CrossRef] [PubMed]

224. Dias, M.M.; Pignon, J.P.; Karapetis, C.S.; Boige, V.; Glimelius, B.; Kweekel, D.M.; Lara, P.N.; Laurent-Puig, P.; Martinez-Balibrea, E.; Paez, D.; et al. The effect of the UGT1A1*28 allele on survival after irinotecan-based chemotherapy: A collaborative meta-analysis. Pharmacogenom. J. 2014, 14, 424-431. [CrossRef] [PubMed]

225. Falvella, F.S.; Cheli, S.; Martinetti, A.; Mazzali, C.; Iacovelli, R.; Maggi, C.; Gariboldi, M.; Pierotti, M.A.; di Bartolomeo, M.; Sottotetti, E.; et al. DPD and UGT1A1 deficiency in colorectal cancer patients receiving triplet chemotherapy with fluoropyrimidines, oxaliplatin and irinotecan. Br. J. Clin. Pharmacol. 2015, 80, 581-588. [CrossRef] [PubMed] 
226. Ferraldeschi, R.; Minchell, L.J.; Roberts, S.A.; Tobi, S.; Hadfield, K.D.; Blackhall, F.H.; Mullamitha, S.; Wilson, G.; Valle, J.; Saunders, M.; et al. UGT1A1*28 genotype predicts gastrointestinal toxicity in patients treated with intermediate-dose irinotecan. Pharmacogenomics 2009, 10, 733-739. [CrossRef] [PubMed]

227. Han, F.F.; Guo, C.L.; Yu, D.; Zhu, J.; Gong, L.L.; Li, G.R.; Lv, Y.L.; Liu, H.; An, G.Y.; Liu, L.H. Associations between $\mathrm{UGT} 1 \mathrm{~A} 1 * 6$ or UGT1A1*6/*28 polymorphisms and irinotecan-induced neutropenia in Asian cancer patients. Cancer Chemother. Pharmacol. 2014, 73, 779-788. [CrossRef] [PubMed]

228. Han, J.Y.; Lim, H.S.; Park, Y.H.; Lee, S.Y.; Lee, J.S. Integrated pharmacogenetic prediction of irinotecan pharmacokinetics and toxicity in patients with advanced non-small cell lung cancer. Lung Cancer 2009, 63, 115-120. [CrossRef] [PubMed]

229. Han, J.Y.; Lim, H.S.; Shin, E.S.; Yoo, Y.K.; Park, Y.H.; Lee, J.E.; Jang, I.J.; Lee, D.H.; Lee, J.S. Comprehensive analysis of UGT1A polymorphisms predictive for pharmacokinetics and treatment outcome in patients with non-small-cell lung cancer treated with irinotecan and cisplatin. J. Clin. Oncol. 2006, 24, 2237-2244. [CrossRef] [PubMed]

230. Hoskins, J.M.; Goldberg, R.M.; Qu, P.; Ibrahim, J.G.; McLeod, H.L. UGT1A1*28 genotype and irinotecan-induced neutropenia: Dose matters. J. Natl. Cancer Inst. 2007, 99, 1290-1295. [CrossRef] [PubMed]

231. Hu, Z.Y.; Yu, Q.; Pei, Q.; Guo, C. Dose-dependent association between UGT1A1*28 genotype and irinotecan-induced neutropenia: Low doses also increase risk. Clin. Cancer Res. 2010, 16, 3832-3842. [CrossRef] [PubMed]

232. Hu, Z.Y.; Yu, Q.; Zhao, Y.S. Dose-dependent association between UGT1A1*28 polymorphism and irinotecan-induced diarrhoea: A meta-analysis. Eur. J. Cancer 2010, 46, 1856-1865. [CrossRef] [PubMed]

233. Innocenti, F.; Undevia, S.D.; Iyer, L.; Chen, P.X.; Das, S.; Kocherginsky, M.; Karrison, T.; Janisch, L.; Ramirez, J.; Rudin, C.M.; et al. Genetic variants in the UDP-glucuronosyltransferase 1A1 gene predict the risk of severe neutropenia of irinotecan. J. Clin. Oncol. 2004, 22, 1382-1388. [CrossRef] [PubMed]

234. Iyer, L.; Das, S.; Janisch, L.; Wen, M.; Ramirez, J.; Karrison, T.; Fleming, G.F.; Vokes, E.E.; Schilsky, R.L.; Ratain, M.J. UGT1A1*28 polymorphism as a determinant of irinotecan disposition and toxicity. Pharmacogenom. J. 2002, 2, 43-47. [CrossRef]

235. Kim, S.Y.; Y, S.H.; E, K.S.; Kong, S.Y.; Shin, A.; Baek, J.Y.; Jung, K.H. S-1 plus irinotecan and oxaliplatin for the first-line treatment of patients with metastatic colorectal cancer: A prospective phase II study and pharmacogenetic analysis. Br. J. Cancer 2013, 109, 1420-1427. [CrossRef] [PubMed]

236. Kweekel, D.M.; Gelderblom, H.; Van der Straaten, T.; Antonini, N.F.; Punt, C.J.; Guchelaar, H.J. UGT1A1*28 genotype and irinotecan dosage in patients with metastatic colorectal cancer: A Dutch Colorectal Cancer Group study. Br. J. Cancer 2008, 99, 275-282. [CrossRef] [PubMed]

237. Lankisch, T.O.; Schulz, C.; Zwingers, T.; Erichsen, T.J.; Manns, M.P.; Heinemann, V.; Strassburg, C.P. Gilbert's Syndrome and irinotecan toxicity: Combination with UDP-glucuronosyltransferase 1A7 variants increases risk. Cancer Epidemiol. Biomark. Prev. 2008, 17, 695-701. [CrossRef] [PubMed]

238. Levesque, E.; Belanger, A.S.; Harvey, M.; Couture, F.; Jonker, D.; Innocenti, F.; Cecchin, E.; Toffoli, G.; Guillemette, C. Refining the UGT1A haplotype associated with irinotecan-induced hematological toxicity in metastatic colorectal cancer patients treated with 5-fluorouracil/irinotecan-based regimens. J. Pharmacol. Exp. Ther. 2013, 345, 95-101. [CrossRef] [PubMed]

239. Li, M.; Wang, Z.; Guo, J.; Liu, J.; Li, C.; Liu, L.; Shi, H.; Liu, L.; Li, H.; Xie, C.; et al. Clinical significance of UGT1A1 gene polymorphisms on irinotecan-based regimens as the treatment in metastatic colorectal cancer. Onco Targets Ther. 2014, 7, 1653-1661. [PubMed]

240. Liu, C.Y.; Chen, P.M.; Chiou, T.J.; Liu, J.H.; Lin, J.K.; Lin, T.C.; Chen, W.S.; Jiang, J.K.; Wang, H.S.; Wang, W.S. UGT1A ${ }^{*} 28$ polymorphism predicts irinotecan-induced severe toxicities without affecting treatment outcome and survival in patients with metastatic colorectal carcinoma. Cancer 2008, 112, 1932-1940. [CrossRef] [PubMed]

241. Liu, X.; Cheng, D.; Kuang, Q.; Liu, G.; Xu, W. Association of UGT1A1*28 polymorphisms with irinotecan-induced toxicities in colorectal cancer: A meta-analysis in Caucasians. Pharmacogenom. J. 2014, 14, 120-129. [CrossRef] [PubMed]

242. Lu, Y.Y.; Huang, X.E.; Wu, X.Y.; Cao, J.; Liu, J.; Wang, L.; Xiang, J. Clinical observations on associations between the UGT1A1 genotype and severe toxicity of irinotecan. Asian Pac. J. Cancer Prev. 2014, 15, 3335-3341. [CrossRef] [PubMed] 
243. Marcuello, E.; Altes, A.; Menoyo, A.; Del Rio, E.; Gomez-Pardo, M.; Baiget, M. UGT1A1 gene variations and irinotecan treatment in patients with metastatic colorectal cancer. Br. J. Cancer 2004, 91, 678-682. [CrossRef] [PubMed]

244. Massacesi, C.; Terrazzino, S.; Marcucci, F.; Rocchi, M.B.; Lippe, P.; Bisonni, R.; Lombardo, M.; Pilone, A.; Mattioli, R.; Leon, A. Uridine diphosphate glucuronosyl transferase 1A1 promoter polymorphism predicts the risk of gastrointestinal toxicity and fatigue induced by irinotecan-based chemotherapy. Cancer 2006, 106, 1007-1016. [CrossRef] [PubMed]

245. Onoue, M.; Terada, T.; Kobayashi, M.; Katsura, T.; Matsumoto, S.; Yanagihara, K.; Nishimura, T.; Kanai, M.; Teramukai, S.; Shimizu, A.; et al. UGT1A1*6 polymorphism is most predictive of severe neutropenia induced by irinotecan in Japanese cancer patients. Int. J. Clin. Oncol. 2009, 14, 136-142. [CrossRef] [PubMed]

246. Rouits, E.; Boisdron-Celle, M.; Dumont, A.; Guerin, O.; Morel, A.; Gamelin, E. Relevance of different UGT1A1 polymorphisms in irinotecan-induced toxicity: A molecular and clinical study of 75 patients. m 2004, 10, 5151-5159. [CrossRef] [PubMed]

247. Rouits, E.; Charasson, V.; Petain, A.; Boisdron-Celle, M.; Delord, J.P.; Fonck, M.; Laurand, A.; Poirier, A.L.; Morel, A.; Chatelut, E.; et al. Pharmacokinetic and pharmacogenetic determinants of the activity and toxicity of irinotecan in metastatic colorectal cancer patients. Br. J. Cancer 2008, 99, 1239-1245. [CrossRef] [PubMed]

248. Ruzzo, A.; Graziano, F.; Loupakis, F.; Santini, D.; Catalano, V.; Bisonni, R.; Ficarelli, R.; Fontana, A.; Andreoni, F.; Falcone, A.; et al. Pharmacogenetic profiling in patients with advanced colorectal cancer treated with first-line FOLFIRI chemotherapy. Pharmacogenom. J. 2008, 8, 278-288. [CrossRef] [PubMed]

249. Stewart, C.F.; Panetta, J.C.; O'Shaughnessy, M.A.; Throm, S.L.; Fraga, C.H.; Owens, T.; Liu, T.; Billups, C.; Rodriguez-Galindo, C.; Gajjar, A.; et al. UGT1A1 promoter genotype correlates with SN-38 pharmacokinetics, but not severe toxicity in patients receiving low-dose irinotecan. J. Clin. Oncol. 2007, 25, 2594-2600. [CrossRef] [PubMed]

250. Takano, M.; Kato, M.; Yoshikawa, T.; Sasaki, N.; Hirata, J.; Furuya, K.; Takahashi, M.; Yokota, H.; Kino, N.; Horie, K.; et al. Clinical significance of UDP-glucuronosyltransferase $1 \mathrm{~A} 1 * 6$ for toxicities of combination chemotherapy with irinotecan and cisplatin in gynecologic cancers: A prospective multi-institutional study. Oncology 2009, 76, 315-321. [CrossRef] [PubMed]

251. Yang, C.; Liu, Y.; Xi, W.Q.; Zhou, C.F.; Jiang, J.L.; Ma, T.; Ye, Z.B.; Zhang, J.; Zhu, Z.G. Relationship between UGT1A $1 * 6 /{ }^{*} 28$ polymorphisms and severe toxicities in Chinese patients with pancreatic or biliary tract cancer treated with irinotecan-containing regimens. Drug Des. Dev. Ther. 2015, 9, 3677-3683.

252. Atasilp, C.; Chansriwong, P.; Sirachainan, E.; Reungwetwattana, T.; Chamnanphon, M.; Puangpetch, A.; Wongwaisayawan, S.; Sukasem, C. Correlation of UGT1A1*28 and *6 polymorphisms with irinotecaninduced neutropenia in Thai colorectal cancer patients. Drug Metab. Pharmacokinet. 2016, 31, 90-94. [CrossRef] [PubMed]

253. Takano, M.; Yamamoto, K.; Tabata, T.; Minegishi, Y.; Yokoyama, T.; Hirata, E.; Ikeda, T.; Shimada, M.; Yamada, K.; Morita, S.; et al. Impact of UGT1A1 genotype upon toxicities of combination with low-dose irinotecan plus platinum. Asia Pac. J. Clin. Oncol. 2016, 12, 115-124. [CrossRef] [PubMed]

254. Xu, Q.; Ding, Y.Y.; Song, L.X.; Xu, J.F. Correlation of UGT1A1 and ERCC1 gene polymorphisms with the outcome of combined irinotecan plus cisplatin treatment in recurrent ovarian cancer. Genet. Mol. Res. 2015, 14, 7241-7247. [CrossRef] [PubMed]

255. Relling, M.V.; Gardner, E.E.; Sandborn, W.J.; Schmiegelow, K.; Pui, C.H.; Yee, S.W.; Stein, C.M.; Carrillo, M.; Evans, W.E.; Hicks, J.K.; et al. Clinical pharmacogenetics implementation consortium guidelines for thiopurine methyltransferase genotype and thiopurine dosing: 2013 update. Clin. Pharmacol. Ther. 2013, 89, 387-391. [CrossRef] [PubMed]

256. Relling, M.V.; Gardner, E.E.; Sandborn, W.J.; Schmiegelow, K.; Pui, C.H.; Yee, S.W.; Stein, C.M.; Carrillo, M.; Evans, W.E.; Klein, T.E. Clinical Pharmacogenetics Implementation Consortium guidelines for thiopurine methyltransferase genotype and thiopurine dosing. Clin. Pharmacol. Ther. 2011, 93, 324-325. [CrossRef] [PubMed]

257. Szumlanski, C.; Otterness, D.; Her, C.; Lee, D.; Brandriff, B.; Kelsell, D.; Spurr, N.; Lennard, L.; Wieben, E.; Weinshilboum, R. Thiopurine methyltransferase pharmacogenetics: Human gene cloning and characterization of a common polymorphism. DNA Cell Biol. 1996, 15, 17-30. [CrossRef] [PubMed]

258. Weinshilboum, R.M.; Sladek, S.L. Mercaptopurine pharmacogenetics: Monogenic inheritance of erythrocyte thiopurine methyltransferase activity. Am. J. Hum. Genet. 1980, 32, 651-662. [PubMed] 
259. Collie-Duguid, E.S.; Pritchard, S.C.; Powrie, R.H.; Sludden, J.; Collier, D.A.; Li, T.; McLeod, H.L. The frequency and distribution of thiopurine methyltransferase alleles in Caucasian and Asian populations. Pharmacogenetics 1999, 9, 37-42. [CrossRef] [PubMed]

260. Appell, M.L.; Berg, J.; Duley, J.; Evans, W.E.; Kennedy, M.A.; Lennard, L.; Marinaki, T.; McLeod, H.L.; Relling, M.V.; Schaeffeler, E.; et al. Nomenclature for alleles of the thiopurine methyltransferase gene. Pharmacogenet. Genom. 2013, 23, 242-248. [CrossRef] [PubMed]

261. Swen, J.J.; Nijenhuis, M.; de Boer, A.; Grandia, L.; Maitland-van der Zee, A.H.; Mulder, H.; Rongen, G.A.; van Schaik, R.H.; Schalekamp, T.; Touw, D.J.; et al. Pharmacogenetics: From bench to byte-An update of guidelines. Clin. Pharmacol. Ther. 2011, 89, 662-673. [CrossRef] [PubMed]

262. Zaza, G.; Cheok, M.; Krynetskaia, N.; Thorn, C.; Stocco, G.; Hebert, J.M.; McLeod, H.; Weinshilboum, R.M.; Relling, M.V.; Evans, W.E.; et al. Thiopurine pathway. Pharmacogenet. Genom. 2010, 20, 573. [CrossRef] [PubMed]

263. Carter, M.; Jemth, A.S.; Hagenkort, A.; Page, B.D.; Gustafsson, R.; Griese, J.J.; Gad, H.; Valerie, N.C.; Desroses, M.; Bostrom, J.; et al. Crystal structure, biochemical and cellular activities demonstrate separate functions of MTH1 and MTH2. Nat. Commun. 2015, 6, 7871. [CrossRef] [PubMed]

264. Ruggiero, A.; Trombatore, G.; Triarico, S.; Arena, R.; Ferrara, P.; Scalzone, M.; Pierri, F.; Riccardi, R. Platinum compounds in children with cancer: Toxicity and clinical management. Anticancer Drugs 2013, 24, 1007-1019. [CrossRef] [PubMed]

265. Hartmann, J.T.; Lipp, H.P. Toxicity of platinum compounds. Expert Opin. Pharmacother. 2003, 4, 889-901. [CrossRef] [PubMed]

266. Skinner, R.; Parry, A.; Price, L.; Cole, M.; Craft, A.W.; Pearson, A.D. Persistent nephrotoxicity during 10-year follow-up after cisplatin or carboplatin treatment in childhood: Relevance of age and dose as risk factors. Eur. J. Cancer 2009, 45, 3213-3219. [CrossRef] [PubMed]

267. Zsiros, J.; Brugieres, L.; Brock, P.; Roebuck, D.; Maibach, R.; Zimmermann, A.; Childs, M.; Pariente, D.; Laithier, V.; Otte, J.B.; et al. Dose-dense cisplatin-based chemotherapy and surgery for children with high-risk hepatoblastoma (SIOPEL-4): A prospective, single-arm, feasibility study. Lancet. Oncol. 2013, 14, 834-842. [CrossRef]

268. Karasawa, T.; Steyger, P.S. An integrated view of cisplatin-induced nephrotoxicity and ototoxicity. Toxicol. Lett. 2015, 237, 219-227. [CrossRef] [PubMed]

269. Cheung, N.V.; Heller, G. Chemotherapy dose intensity correlates strongly with response, median survival, and median progression-free survival in metastatic neuroblastoma. J. Clin. Oncol. 1991, 9, 1050-1058. [PubMed]

270. Ross, C.J.; Katzov-Eckert, H.; Dube, M.P.; Brooks, B.; Rassekh, S.R.; Barhdadi, A.; Feroz-Zada, Y.; Visscher, H.; Brown, A.M.; Rieder, M.J.; et al. Genetic variants in TPMT and COMT are associated with hearing loss in children receiving cisplatin chemotherapy. Nat. Genet. 2009, 41, 1345-1349. [CrossRef] [PubMed]

271. Hagleitner, M.M.; Coenen, M.J.; Patino-Garcia, A.; de Bont, E.S.; Gonzalez-Neira, A.; Vos, H.I.; van Leeuwen, F.N.; Gelderblom, H.; Hoogerbrugge, P.M.; Guchelaar, H.J.; et al. Influence of genetic variants in TPMT and COMT associated with cisplatin induced hearing loss in patients with cancer: Two new cohorts and a meta-analysis reveal significant heterogeneity between cohorts. PLoS ONE 2014, 9, e115869. [CrossRef] [PubMed]

272. Yang, J.J.; Lim, J.Y.; Huang, J.; Bass, J.; Wu, J.; Wang, C.; Fang, J.; Stewart, E.; Harstead, E.H.; Robinson, G.W.; et al. The role of inherited TPMT and COMT genetic variation in cisplatin-induced ototoxicity in children with cancer. Clin. Pharmacol. Ther. 2013, 94, 252-259. [CrossRef] [PubMed]

273. Pussegoda, K.; Ross, C.J.; Visscher, H.; Yazdanpanah, M.; Brooks, B.; Rassekh, S.R.; Zada, Y.F.; Dube, M.P.; Carleton, B.C.; Hayden, M.R.; et al. Replication of TPMT and ABCC3 genetic variants highly associated with cisplatin-induced hearing loss in children. Clin. Pharmacol. Ther. 2013, 94, 243-251. [CrossRef] [PubMed]

274. Assaraf, Y.G. Molecular basis of antifolate resistance. Cancer Metastasis Rev. 2007, 26, 153-181. [CrossRef] [PubMed]

275. Farber, S.; Diamond, L.K. Temporary remissions in acute leukemia in children produced by folic acid antagonist, 4-aminopteroyl-glutamic acid. N. Engl. J. Med. 1948, 238, 787-793. [CrossRef] [PubMed]

276. Escherich, G.; Horstmann, M.A.; Zimmermann, M.; Janka-Schaub, G.E. Cooperative study group for childhood acute lymphoblastic leukaemia (COALL): Long-term results of trials 82, 85, 89, 92 and 97. Leukemia 2010, 24, 298-308. [CrossRef] [PubMed] 
277. Hunger, S.P.; Lu, X.; Devidas, M.; Camitta, B.M.; Gaynon, P.S.; Winick, N.J.; Reaman, G.H.; Carroll, W.L. Improved survival for children and adolescents with acute lymphoblastic leukemia between 1990 and 2005: A report from the children's oncology group. J. Clin. Oncol. 2012, 30, 1663-1669. [CrossRef] [PubMed]

278. Kodidela, S.; Suresh Chandra, P.; Dubashi, B. Pharmacogenetics of methotrexate in acute lymphoblastic leukaemia: Why still at the bench level? Eur. J. Clin. Pharmacol. 2014, 70, 253-260. [CrossRef] [PubMed]

279. Moricke, A.; Zimmermann, M.; Reiter, A.; Henze, G.; Schrauder, A.; Gadner, H.; Ludwig, W.D.; Ritter, J.; Harbott, J.; Mann, G.; et al. Long-term results of five consecutive trials in childhood acute lymphoblastic leukemia performed by the ALL-BFM study group from 1981 to 2000. Leukemia 2010, 24, 265-284. [CrossRef] [PubMed]

280. Ramsey, L.B.; Bruun, G.H.; Yang, W.; Trevino, L.R.; Vattathil, S.; Scheet, P.; Cheng, C.; Rosner, G.L.; Giacomini, K.M.; Fan, Y.; et al. Rare versus common variants in pharmacogenetics: SLCO1B1 variation and methotrexate disposition. Genome Res. 2012, 22, 1-8. [CrossRef] [PubMed]

281. Prasad, B.; Evers, R.; Gupta, A.; Hop, C.E.; Salphati, L.; Shukla, S.; Ambudkar, S.V.; Unadkat, J.D. Interindividual variability in hepatic organic anion-transporting polypeptides and P-glycoprotein (ABCB1) protein expression: Quantification by liquid chromatography tandem mass spectroscopy and influence of genotype, age, and sex. Drug Metab. Dispos. 2014, 42, 78-88. [CrossRef] [PubMed]

282. Ulvestad, M.; Skottheim, I.B.; Jakobsen, G.S.; Bremer, S.; Molden, E.; Asberg, A.; Hjelmesaeth, J.; Andersson, T.B.; Sandbu, R.; Christensen, H. Impact of OATP1B1, MDR1, and CYP3A4 expression in liver and intestine on interpatient pharmacokinetic variability of atorvastatin in obese subjects. Clin. Pharmacol. Ther. 2013, 93, 275-282. [CrossRef] [PubMed]

283. Ansari, M.; Sauty, G.; Labuda, M.; Gagne, V.; Laverdiere, C.; Moghrabi, A.; Sinnett, D.; Krajinovic, M. Polymorphisms in multidrug resistance-associated protein gene 4 is associated with outcome in childhood acute lymphoblastic leukemia. Blood 2009, 114, 1383-1386. [CrossRef] [PubMed]

284. Ansari, M.; Sauty, G.; Labuda, M.; Gagne, V.; Rousseau, J.; Moghrabi, A.; Laverdiere, C.; Sinnett, D.; Krajinovic, M. Polymorphism in multidrug resistance-associated protein gene 3 is associated with outcomes in childhood acute lymphoblastic leukemia. Pharmacogenom. J. 2012, 12, 386-394. [CrossRef] [PubMed]

285. Laverdiere, C.; Chiasson, S.; Costea, I.; Moghrabi, A.; Krajinovic, M. Polymorphism G80A in the reduced folate carrier gene and its relationship to methotrexate plasma levels and outcome of childhood acute lymphoblastic leukemia. Blood 2002, 100, 3832-3834. [CrossRef] [PubMed]

286. Radtke, S.; Zolk, O.; Renner, B.; Paulides, M.; Zimmermann, M.; Moricke, A.; Stanulla, M.; Schrappe, M.; Langer, T. Germline genetic variations in methotrexate candidate genes are associated with pharmacokinetics, toxicity, and outcome in childhood acute lymphoblastic leukemia. Blood 2013, 121, 5145-5153. [CrossRef] [PubMed]

287. Al-Shakfa, F.; Dulucq, S.; Brukner, I.; Milacic, I.; Ansari, M.; Beaulieu, P.; Moghrabi, A.; Laverdiere, C.; Sallan, S.E.; Silverman, L.B.; et al. DNA variants in region for noncoding interfering transcript of dihydrofolate reductase gene and outcome in childhood acute lymphoblastic leukemia. Clin. Cancer Res. 2009, 15, 6931-6938. [CrossRef] [PubMed]

288. Dulucq, S.; St-Onge, G.; Gagne, V.; Ansari, M.; Sinnett, D.; Labuda, D.; Moghrabi, A.; Krajinovic, M. DNA variants in the dihydrofolate reductase gene and outcome in childhood ALL. Blood 2008, 111, 3692-3700. [CrossRef] [PubMed]

289. Kodidela, S.; Pradhan, S.C.; Dubashi, B.; Basu, D. Influence of dihydrofolate reductase gene polymorphisms rs408626 $(-317 \mathrm{~A}>\mathrm{G})$ and $\mathrm{rs} 442767(-680 \mathrm{C}>\mathrm{A})$ on the outcome of methotrexate-based maintenance therapy in South Indian patients with acute lymphoblastic leukemia. Eur. J. Clin. Pharmacol. 2015, 71, 1349-1358. [CrossRef] [PubMed]

290. Krajinovic, M.; Costea, I.; Chiasson, S. Polymorphism of the thymidylate synthase gene and outcome of acute lymphoblastic leukaemia. Lancet 2002, 359, 1033-1034. [CrossRef]

291. Krajinovic, M.; Costea, I.; Primeau, M.; Dulucq, S.; Moghrabi, A. Combining several polymorphisms of thymidylate synthase gene for pharmacogenetic analysis. Pharmacogenom. J. 2005, 5, 374-380. [CrossRef] [PubMed]

292. Relling, M.V.; Yang, W.; Das, S.; Cook, E.H.; Rosner, G.L.; Neel, M.; Howard, S.; Ribeiro, R.; Sandlund, J.T.; Pui, C.H.; et al. Pharmacogenetic risk factors for osteonecrosis of the hip among children with leukemia. J. Clin. Oncol. 2004, 22, 3930-3936. [CrossRef] [PubMed] 
293. Thompson, H.R.; Jones, G.M.; Narkewicz, M.R. Ontogeny of hepatic enzymes involved in serine- and folate-dependent one-carbon metabolism in rabbits. Am. J. Physiol. Gastrointest. Liver Physiol. 2001, 280, G873-G878. [CrossRef] [PubMed]

294. Kantarjian, H.; Thomas, D.; O'Brien, S.; Cortes, J.; Giles, F.; Jeha, S.; Bueso-Ramos, C.E.; Pierce, S.; Shan, J.; Koller, C.; et al. Long-term follow-up results of hyperfractionated cyclophosphamide, vincristine, doxorubicin, and dexamethasone (Hyper-CVAD), a dose-intensive regimen, in adult acute lymphocytic leukemia. Cancer 2004, 101, 2788-2801. [CrossRef] [PubMed]

295. Larson, R.A.; Dodge, R.K.; Burns, C.P.; Lee, E.J.; Stone, R.M.; Schulman, P.; Duggan, D.; Davey, F.R.; Sobol, R.E.; Frankel, S.R.; et al. A five-drug remission induction regimen with intensive consolidation for adults with acute lymphoblastic leukemia: Cancer and leukemia group B study 8811. Blood 1995, 85, 2025-2037. [PubMed]

296. Gorlick, R.; Janeway, K.; Lessnick, S.; Randall, R.L.; Marina, N.; COG Bone Tumor Committee. Children's Oncology Group's 2013 blueprint for research: Bone tumors. Pediatr. Blood Cancer 2013, 60, 1009-1015. [CrossRef] [PubMed]

297. Malempati, S.; Hawkins, D.S. Rhabdomyosarcoma: Review of the Children's Oncology Group (COG) Soft-Tissue Sarcoma Committee experience and rationale for current COG studies. Pediatr. Blood Cancer 2012, 59, 5-10. [CrossRef] [PubMed]

298. Friedman, H.S.; Bigner, S.H.; Bigner, D.D. Cyclophosphamide therapy of medulloblastoma: From the laboratory to the clinic and back again (and again and again). J. Neurooncol. 1995, 24, 103-108. [CrossRef] [PubMed]

299. Zhang, J.; Tian, Q.; Yung Chan, S.; Chuen Li, S.; Zhou, S.; Duan, W.; Zhu, Y.Z. Metabolism and transport of oxazaphosphorines and the clinical implications. Drug Metab. Rev. 2005, 37, 611-703. [CrossRef] [PubMed]

300. Bohnenstengel, F.; Hofmann, U.; Eichelbaum, M.; Kroemer, H.K. Characterization of the cytochrome P450 involved in side-chain oxidation of cyclophosphamide in humans. Eur. J. Clin. Pharmacol. 1996, 51, 297-301. [CrossRef] [PubMed]

301. Chang, T.K.; Weber, G.F.; Crespi, C.L.; Waxman, D.J. Differential activation of cyclophosphamide and ifosphamide by cytochromes P-450 2B and 3A in human liver microsomes. Cancer Res. 1993, 53, 5629-5637. [PubMed]

302. Ren, S.; Yang, J.S.; Kalhorn, T.F.; Slattery, J.T. Oxidation of cyclophosphamide to 4-hydroxycyclophosphamide and deschloroethylcyclophosphamide in human liver microsomes. Cancer Res. 1997, 57, 4229-4235. [PubMed]

303. Moghe, A.; Ghare, S.; Lamoreau, B.; Mohammad, M.; Barve, S.; McClain, C.; Joshi-Barve, S. Molecular mechanisms of acrolein toxicity: Relevance to human disease. Toxicol. Sci. 2015, 143, 242-255. [CrossRef] [PubMed]

304. Dirven, H.A.; van Ommen, B.; van Bladeren, P.J. Involvement of human glutathione S-transferase isoenzymes in the conjugation of cyclophosphamide metabolites with glutathione. Cancer Res. 1994, 54, 6215-6120. [PubMed]

305. Dirven, H.A.; Venekamp, J.C.; van Ommen, B.; van Bladeren, P.J. The interaction of glutathione with 4-hydroxycyclophosphamide and phosphoramide mustard, studied by 31P nuclear magnetic resonance spectroscopy. Chem. Biol. Interact. 1994, 93, 185-196. [CrossRef]

306. Ekhart, C.; Doodeman, V.D.; Rodenhuis, S.; Smits, P.H.; Beijnen, J.H.; Huitema, A.D. Influence of polymorphisms of drug metabolizing enzymes (CYP2B6, CYP2C9, CYP2C19, CYP3A4, CYP3A5, GSTA1, GSTP1, ALDH1A1 and ALDH3A1) on the pharmacokinetics of cyclophosphamide and 4-hydroxycyclophosphamide. Pharmacogenet. Genom. 2008, 18, 515-523. [CrossRef] [PubMed]

307. Nakajima, M.; Komagata, S.; Fujiki, Y.; Kanada, Y.; Ebi, H.; Itoh, K.; Mukai, H.; Yokoi, T.; Minami, H. Genetic polymorphisms of CYP2B6 affect the pharmacokinetics/pharmacodynamics of cyclophosphamide in Japanese cancer patients. Pharmacogenet. Genom. 2007, 17, 431-445. [CrossRef] [PubMed]

308. Timm, R.; Kaiser, R.; Lotsch, J.; Heider, U.; Sezer, O.; Weisz, K.; Montemurro, M.; Roots, I.; Cascorbi, I. Association of cyclophosphamide pharmacokinetics to polymorphic cytochrome P450 2 C19. Pharmacogenom. J. 2005, 5, 365-373. [CrossRef] [PubMed]

309. Veal, G.J.; Cole, M.; Chinnaswamy, G.; Sludden, J.; Jamieson, D.; Errington, J.; Malik, G.; Hill, C.R.; Chamberlain, T.; Boddy, A.V. Cyclophosphamide pharmacokinetics and pharmacogenetics in children with B-cell non-Hodgkin's lymphoma. Eur. J. Cancer 2016, 55, 56-64. [CrossRef] [PubMed] 
310. Wagner, L.M. Fifteen years of irinotecan therapy for pediatric sarcoma: Where to next? Clin. Sarcoma Res. 2015, 5, 20. [CrossRef] [PubMed]

311. Mathijssen, R.H.; van Alphen, R.J.; Verweij, J.; Loos, W.J.; Nooter, K.; Stoter, G.; Sparreboom, A. Clinical pharmacokinetics and metabolism of irinotecan (CPT-11). Clin. Cancer Res. 2001, 7, 2182-2194. [PubMed]

312. Saltz, L.B.; Cox, J.V.; Blanke, C.; Rosen, L.S.; Fehrenbacher, L.; Moore, M.J.; Maroun, J.A.; Ackland, S.P.; Locker, P.K.; Pirotta, N.; et al. Irinotecan plus fluorouracil and leucovorin for metastatic colorectal cancer. N. Engl. J. Med. 2000, 343, 905-914. [CrossRef] [PubMed]

313. Hines, R.N. The ontogeny of drug metabolism enzymes and implications for adverse drug events. Pharmacol. Ther. 2008, 118, 250-267. [CrossRef] [PubMed]

314. Zhang, D.; Zhang, D.; Cui, D.; Gambardella, J.; Ma, L.; Barros, A.; Wang, L.; Fu, Y.; Rahematpura, S.; Nielsen, J.; et al. Characterization of the UDP glucuronosyltransferase activity of human liver microsomes genotyped for the UGT1A1*28 polymorphism. Drug Metab. Dispos. 2007, 35, 2270-2280. [CrossRef] [PubMed]

315. Gagne, J.F.; Montminy, V.; Belanger, P.; Journault, K.; Gaucher, G.; Guillemette, C. Common human UGT1A polymorphisms and the altered metabolism of irinotecan active metabolite 7-ethyl-10-hydroxycamptothecin (SN-38). Mol. Pharmacol. 2002, 62, 608-617. [CrossRef] [PubMed]

316. Etienne-Grimaldi, M.C.; Boyer, J.C.; Thomas, F.; Quaranta, S.; Picard, N.; Loriot, M.A.; Narjoz, C.; Poncet, D.; Gagnieu, M.C.; Ged, C.; et al. UGT1A1 genotype and irinotecan therapy: General review and implementation in routine practice. Fundam. Clin. Pharmacol. 2015, 29, 219-237. [CrossRef] [PubMed]

317. DuBois, S.G.; Allen, S.; Bent, M.; Hilton, J.F.; Hollinger, F.; Hawkins, R.; Courtier, J.; Mosse, Y.P.; Matthay, K.K. Phase I/II study of ${ }^{131} \mathrm{I}-\mathrm{MIBG}$ with vincristine and 5 days of irinotecan for advanced neuroblastoma. Br. J. Cancer 2015, 112, 644-649. [CrossRef] [PubMed]

318. DuBois, S.G.; Chesler, L.; Groshen, S.; Hawkins, R.; Goodarzian, F.; Shimada, H.; Yanik, G.; Tagen, M.; Stewart, C.; Mosse, Y.P.; et al. Phase I study of vincristine, irinotecan, and ${ }^{131}$ I-metaiodobenzylguanidine for patients with relapsed or refractory neuroblastoma: A new approaches to neuroblastoma therapy trial. Clin. Cancer Res. 2012, 18, 2679-2686. [CrossRef] [PubMed]

319. Cole-Healy, Z.; Vergani, P.; Hunter, K.; Brown, N.J.; Reed, M.W.; Staton, C.A. The relationship between semaphorin 3C and microvessel density in the progression of breast and oral neoplasia. Exp. Mol. Pathol. 2015, 99, 19-24. [CrossRef] [PubMed]

320. Man, J.; Shoemake, J.; Zhou, W.; Fang, X.; Wu, Q.; Rizzo, A.; Prayson, R.; Bao, S.; Rich, J.N.; Yu, J.S. Sema3C promotes the survival and tumorigenicity of glioma stem cells through Rac1 activation. Cell. Rep. 2014, 9, 1812-1826. [CrossRef] [PubMed]

321. Miyato, H.; Tsuno, N.H.; Kitayama, J. Semaphorin 3C is involved in the progression of gastric cancer. Cancer Sci. 2012, 103, 1961-1966. [CrossRef] [PubMed]

322. Pui, C.H.; Evans, W.E. Treatment of acute lymphoblastic leukemia. N. Engl. J. Med. 2006, 354, $166-178$. [CrossRef] [PubMed]

323. Jordan, M.A.; Toso, R.J.; Thrower, D.; Wilson, L. Mechanism of mitotic block and inhibition of cell proliferation by taxol at low concentrations. Proc. Natl. Acad. Sci. USA 1993, 90, 9552-9556. [CrossRef] [PubMed]

324. Egbelakin, A.; Ferguson, M.J.; MacGill, E.A.; Lehmann, A.S.; Topletz, A.R.; Quinney, S.K.; Li, L.; McCammack, K.C.; Hall, S.D.; Renbarger, J.L. Increased risk of vincristine neurotoxicity associated with low CYP3A5 expression genotype in children with acute lymphoblastic leukemia. Pediatr. Blood Cancer 2011, 56, 361-367. [CrossRef] [PubMed]

325. Xie, H.G.; Wood, A.J.; Kim, R.B.; Stein, C.M.; Wilkinson, G.R. Genetic variability in CYP3A5 and its possible consequences. Pharmacogenomics 2004, 5, 243-272. [CrossRef] [PubMed]

326. Dennison, J.B.; Jones, D.R.; Renbarger, J.L.; Hall, S.D. Effect of CYP3A5 expression on vincristine metabolism with human liver microsomes. J. Pharmacol. Exp. Ther. 2007, 321, 553-563. [CrossRef] [PubMed]

327. Dennison, J.B.; Kulanthaivel, P.; Barbuch, R.J.; Renbarger, J.L.; Ehlhardt, W.J.; Hall, S.D. Selective metabolism of vincristine in vitro by CYP3A5. Drug Metab. Dispos. 2006, 34, 1317-1327. [CrossRef] [PubMed]

328. Guilhaumou, R.; Simon, N.; Quaranta, S.; Verschuur, A.; Lacarelle, B.; Andre, N.; Solas, C. Population pharmacokinetics and pharmacogenetics of vincristine in paediatric patients treated for solid tumour diseases. Cancer Chemother. Pharmacol. 2011, 68, 1191-1198. [CrossRef] [PubMed] 
329. Moore, A.S.; Norris, R.; Price, G.; Nguyen, T.; Ni, M.; George, R.; van Breda, K.; Duley, J.; Charles, B.; Pinkerton, R. Vincristine pharmacodynamics and pharmacogenetics in children with cancer: A limited-sampling, population modelling approach. J. Paediatr. Child. Health 2011, 47, 875-882. [CrossRef] [PubMed]

330. Sims, R.P. The effect of race on the CYP3A-mediated metabolism of vincristine in pediatric patients with acute lymphoblastic leukemia. J. Oncol. Pharm. Pract. 2016, 22, 76-81. [CrossRef] [PubMed]

331. Diouf, B.; Crews, K.R.; Lew, G.; Pei, D.; Cheng, C.; Bao, J.; Zheng, J.J.; Yang, W.; Fan, Y.; Wheeler, H.E.; et al. Association of an inherited genetic variant with vincristine-related peripheral neuropathy in children with acute lymphoblastic leukemia. JAMA 2015, 313, 815-823. [CrossRef] [PubMed]

332. Gutierrez-Camino, A.; Martin-Guerrero, I.; Lopez-Lopez, E.; Echebarria-Barona, A.; Zabalza, I.; Ruiz, I.; Guerra-Merino, I.; Garcia-Orad, A. Lack of association of the CEP72 rs924607 TT genotype with vincristine-related peripheral neuropathy during the early phase of pediatric acute lymphoblastic leukemia treatment in a Spanish population. Pharmacogenet. Genom. 2016, 26, 100-102. [CrossRef] [PubMed]

333. Bosilkovska, M.; Ing Lorenzini, K.; Uppugunduri, C.R.; Desmeules, J.; Daali, Y.; Escher, M. Severe Vincristine-induced Neuropathic Pain in a CYP3A5 Nonexpressor With Reduced CYP3A4/5 Activity: Case Study. Clin. Ther. 2016, 38, 216-220. [CrossRef] [PubMed]

334. Ceppi, F.; Langlois-Pelletier, C.; Gagne, V.; Rousseau, J.; Ciolino, C.; de Lorenzo, S.; Kevin, K.M.; Cijov, D.; Sallan, S.E.; Silverman, L.B.; et al. Polymorphisms of the vincristine pathway and response to treatment in children with childhood acute lymphoblastic leukemia. Pharmacogenomics 2014, 15, 1105-1116. [CrossRef] [PubMed]

335. Efferth, T.; Sauerbrey, A.; Steinbach, D.; Gebhart, E.; Drexler, H.G.; Miyachi, H.; Chitambar, C.R.; Becker, C.M.; Zintl, F; Humeny, A. Analysis of single nucleotide polymorphism C3435T of the multidrug resistance gene MDR1 in acute lymphoblastic leukemia. Int. J. Oncol. 2003, 23, 509-517. [CrossRef] [PubMed]

336. Jamroziak, K.; Balcerczak, E.; Cebula, B.; Kowalczyk, M.; Panczyk, M.; Janus, A.; Smolewski, P.; Mirowski, M.; Robak, T. Multi-drug transporter MDR1 gene polymorphism and prognosis in adult acute lymphoblastic leukemia. Pharmacol. Rep. 2005, 57, 882-888. [PubMed]

337. Yang, J.J.; Cheng, C.; Devidas, M.; Cao, X.; Campana, D.; Yang, W.; Fan, Y.; Neale, G.; Cox, N.; Scheet, P.; et al. Genome-wide association study identifies germline polymorphisms associated with relapse of childhood acute lymphoblastic leukemia. Blood 2012, 120, 4197-4204. [CrossRef] [PubMed] 